\title{
Locus of control and investment in risky assets
}

Citation for published version (APA):

Salamanca Acosta, N., de Grip, A., Fouarge, D., \& Montizaan, R. (2020). Locus of control and investment in risky assets. Journal of Economic Behavior \& Organization, 177, 548-568.

https://doi.org/10.1016/j.jebo.2020.06.032

Document status and date:

Published: 01/09/2020

DOI:

10.1016/j.jebo.2020.06.032

Document Version:

Publisher's PDF, also known as Version of record

Document license:

Taverne

Please check the document version of this publication:

- A submitted manuscript is the version of the article upon submission and before peer-review. There can be important differences between the submitted version and the official published version of record.

People interested in the research are advised to contact the author for the final version of the publication, or visit the DOI to the publisher's website.

- The final author version and the galley proof are versions of the publication after peer review.

- The final published version features the final layout of the paper including the volume, issue and page numbers.

Link to publication

\footnotetext{
General rights rights.

- You may freely distribute the URL identifying the publication in the public portal. please follow below link for the End User Agreement:

www.umlib.nl/taverne-license

Take down policy

If you believe that this document breaches copyright please contact us at:

repository@maastrichtuniversity.nl

providing details and we will investigate your claim.
}

Copyright and moral rights for the publications made accessible in the public portal are retained by the authors and/or other copyright owners and it is a condition of accessing publications that users recognise and abide by the legal requirements associated with these

- Users may download and print one copy of any publication from the public portal for the purpose of private study or research.

- You may not further distribute the material or use it for any profit-making activity or commercial gain

If the publication is distributed under the terms of Article $25 \mathrm{fa}$ of the Dutch Copyright Act, indicated by the "Taverne" license above, 


\title{
Locus of control and investment in risky assets
}

\author{
Nicolás Salamanca ${ }^{\mathrm{a}, \mathrm{c}, *}$, Andries de Grip ${ }^{\mathrm{b}, \mathrm{c}}$, Didier Fouarge ${ }^{\mathrm{b}, \mathrm{c}}$, \\ Raymond Montizaan ${ }^{\mathrm{b}, \mathrm{c}}$ \\ ${ }^{a}$ Melbourne Institute: Applied Economic E Social Research, University of Melbourne, ARC Centre of Excellence for Children and Families \\ over the Life Course, Australia \\ ${ }^{\mathrm{b}} \mathrm{ROA}$, Maastricht University, and Netspar, The Netherlands \\ ${ }^{\mathrm{c}}$ Institute of Labor Economics (IZA), Germany
}

\section{A R T I C L E I N F O}

\section{Article history:}

Received 25 September 2018

Revised 26 June 2020

Accepted 28 June 2020

Available online 17 July 2020

JEL classification:

D14

D19

G11

Keywords:

Household portfolio

Personality trait

Subjective expectation

Risk perception

Financial literacy

Measurement error

\begin{abstract}
A B S T R A C T
Internal locus of control is an important personality trait strongly related to many economic outcomes. We show that the probability to own equity and the share of equity in household portfolios increase with people's internal locus of control. We explore, and find no evidence for, the hypothesis that this relation is driven by a link between internal economic locus of control and subjective expectations about the return and risk of investment in equity. The relation between locus of control and investment in equity also remains after controlling for risk and time preferences, financial literacy, overconfidence, optimism, trust, and other personality traits. We also show that locus of control has a stronger relation with investment in equity for financially illiterate investors. Our results document a strong and robust relation between locus of control and investment behaviour that cannot be explained by leading behavioural investment theories.
\end{abstract}

(c) 2020 Elsevier B.V. All rights reserved.

\section{Introduction}

Many households invest in the stock market. Around half of U.S. and a third of U.K. households invest in the stock market and, in the Netherlands, about a quarter of all households own stocks or mutual funds (Van Rooij et al., 2011). The widespread participation of household investors in the stock market calls for a better understanding of the determinants of their investment behavior. Although many of these determinants have been previously explored, individual investment behavior largely remains a puzzle. ${ }^{1}$ In particular, we still know little of how personality relates to investment behavior,

\footnotetext{
ty We thank Eric Bonsang, Lex Borghans, Deborah Cobb-Clark, Denis de Crombrugghe, Thomas Dohmen, Alexandra de Gendre, Bart Golsteyn, Thomas Post, Stefanie Schurer, Paul Smeets, Ulf Zölitz, and especially Jan Feld for their helpful suggestions, and participants at various seminars and conferences for their comments. This research was supported by the Australian Research Council Centre of Excellence for Children and Families over the Life Course (project number CE140100027). The Centre is administered by the Institute for Social Science Research at The University of Queensland, with nodes at The University of Western Australia, The University of Melbourne and The University of Sydney. The views expressed herein are those of the authors and are not necessarily those of the Australian Research Council. In this paper use is made of data of the DNB Household Survey.

* Corresponding author at: Level 5, Business and Economics Building, 111 Barry Street, The University of Melbourne, Victoria 3010, Australia.

E-mail address: n.salamanca@unimelb.edu.au (N. Salamanca).

${ }^{1}$ Models of portfolio choice highlight risk and time preferences as the two key determinants of individual investment behavior (e.g., Merton, 1969; Samuelson, 1969; Bodie et al., 1992; Cocco et al., 2005; Gomes and Michaelides, 2005; Benzoni et al., 2007). More recent studies show that social prefer-
} 
even though the importance of personality traits for several other economic outcomes has been extensively researched (e.g., Heckman et al., 2006; Borghans et al., 2008; Almlund et al., 2011).

One especially important personality trait is internal locus of control-the extent to which a person believes that the outcomes in one's life are due to one's own personal efforts, as opposed to the result of luck, change, fate, or the intervention and influence of others (Rotter, 1966) - which has been shown to matter in situations that involve investment. What we know about locus of control suggests that it could also be a key determinant of stock market investment. An extensive literature shows that internal locus of control impacts labor market outcomes that depend on personal investment (e.g., Bowles et al., 2001a; 2001b; Coleman and DeLeire, 2003; Heineck and Anger, 2010; Caliendo et al., 2015; McGee, 2015; McGee and McGee, 2016; Schurer, 2017), as well as the credit market (Tokunaga, 1993) and entrepreneurship (Evans and Leighton, 1989) and savings (Cobb-Clark et al., 2016). Yet we know little about whether locus of control affects investments in risky assets. Recent studies provide valuable insights on this relation in the lab (Pinger et al., 2018; Oehler et al., 2018) but it is unclear whether those insights also apply to people's investment behavior outside the lab. Moreover, this evidence finds conflicting results on the relation between internal locus of control and return expectations, which is perhaps the key determinant of investment behavior.

This paper explores how internal economic locus of control relates to investment decisions in equity. Internal economic locus of control is a measure constructed by Furnham (1986) measures the extent to which individuals believe that their economic outcomes, such as the creation of wealth, are due to their own personal efforts. This measure was adapted from the original locus of control scale (Rotter, 1966), and its main components strongly correlate with the main components of locus of control. ${ }^{2}$ Using representative household data from the Dutch National Bank Household Survey, we show that a one standard deviation increase in people's internal economic locus of control relates to an increase in the probability of investing in equity by 2.3 percentage points and an increase in the portfolio share of equity by 1.3 percentage points. These magnitudes are economically important, corresponding to 8 and $10 \%$ of their unconditional means.

Drawing on previous literature that links locus of control to investment behavior in other domains and settings (e.g., Slovic, 1992; Caliendo et al., 2015; McGee and McGee, 2016; Pinger et al., 2018), we first conjecture a main potential mechanism behind the positive relation between an internal locus of control and investment in equity: people with a strong internal locus of control could expect higher returns and lower risk from their investments in equity. These mechanisms would link locus of control, subjective expectations, and investment, allowing us to understand our main findings through an interpersonal subjective risk-return framework. We find that this mechanism is plausible; having a more internal locus of control is positively related to higher subjective expected returns and lower subjective expected risk from mutual fund investments. However, we also show that internal locus of control still relates to investment in equity even after accounting for these subjective expectations. To the extent that these subjective expectations are correlated with people's return and risk expectations on their own investments, and to market expectations (Weber et al., 2013), these results suggest that the relation between internal locus of control and investment in equity does not operate through people's expected return or risk.

We then consider, and find no evidence for, several other potential explanations for our main results. First, throughout the paper we show that our main results are robust to controlling for measures of risk and time preference measures, the standard determinants of portfolio choice in economics. Second, we also show that the positive relation between internal locus of control and equity investment is not driven by a household's subjective or objective financial literacy. However, the internal locus of control relation with equity ownership is stronger for financially unsophisticated investors, suggesting a commonality between locus of control and many other behavioral biases that are exacerbated in less sophisticated investors. Third, we show that internal locus of control does not act as a proxy for overconfidence, optimism, trust, or the Big Five personality traits. Finally, we show that our main results $i$ ) are not driven by reverse causality; ii) remain robust to the use of alternative definitions of internal locus of control; iii) are mainly driven by the relation between internal locus of control and stock investment and not other equity types; and $i v$ ) that measurement error does not hamper our tests for mechanisms and potential confounders.

We thus document an economically important and statistically robust relation of locus of control to investment behavior over and above the main portfolio choice determinants known to date. Our results highlight the importance of locus of control as a crucial personality trait in determining people's outcomes, while also making substantial progress in exploring the mechanisms through which it operates.

We contribute to the existing literature by establishing the relation between locus of control and investment in risky assets and showing that it is independent of the chief alternative explanations in economic and behavioral finance theory. We further document the relation between locus of control and measures of subjective return and risk perceptions. These

ences and financial literacy also play an important role in portfolio choice (e.g., Hong et al., 2004; Guiso et al., 2008; Van Rooij et al., 2011), and a rapidly growing literature in behavioral finance has further identified optimism and overconfidence as drivers of investment behavior (e.g., De Bondt, 1998; Barber and Odean, 2001; Puri and Robinson, 2007; Grinblatt and Keloharju, 2009). The role of personality on investment behavior has been largely neglected with the exception of McInish (1982) and Durand et al. (2008).

2 Furnham (1986) shows that the internal dimension of economic locus of control positively correlates with Rotter's internal locus of control ( $\hat{r}=0.33$ ), whereas the 'powerful others' dimension of economic locus of control correlates negatively with Rotter's 'internal' dimension of locus of control ( $\hat{r}=-0.31$ ). Plunkett and Buehner (2007) show that a single-dimension measure of internal economic locus of control positively correlates with a single-dimension measure of Rotter's locus of control ( $\hat{r}=0.37$ ). Van Daalen et al. (2008) provide evidence on the reliability and cross-cultural validity of Furnham's scale, while Dohmen et al. (2011), among many others, argue that domain-specific scales for traits and preferences are the best predictors of behavior those specific domains. 
results provide a potential bridge between the influential and growing literature on subjective expectations and investment behavior (Jensen, 2010; Wiswall and Zafar, 2015; Delavande and Kohler, 2016; Baranov and Kohler, 2018) and the studies linking locus of control to various types of investments (Cebi, 2007; Coleman and DeLeire, 2003; Cobb-Clark et al., 2014; Caliendo et al., 2015). Our results thus explore a way in which personality-driven investment behavior could be reconciled with the traditional risk-return framework of portfolio choice. Yet, we also show that this reconciled framework is unlikely to explain our findings, leading us to explore other potential ways to understand the relationship between locus of control and investment.

\section{Data}

We use information from the 1994 to 2015 waves of the Dutch National Bank Household Survey (DHS), an annual panel survey of Dutch households that is representative of the Dutch population over the age of $16 .^{3}$ Members of these households answer extensive questionnaires on household income and wealth, household expenditures, job and occupational status, subjective expectations, and psychological aspects of individual behaviour. The survey also includes detailed measures of household assets, including their financial portfolios.

For our analyses we only use the information provided by household heads responsible for the household's finances, since these respondents report the entire household's asset holdings. We restrict our sample to household heads between the ages of 25 and 80 who are neither studying full time, looking for employment for the first time, or solely living on government benefits. Finally, we only keep households that report a positive amount of financial wealth and cash holdings, and only include households for which we have data on financial assets and measures of internal economic locus of control. After these restrictions our main estimation sample includes 3151 households, for a total of 18,420 household-year observations. ${ }^{4}$

\subsection{Measuring equity and financial wealth}

We define equity ownership as owning a positive amount of at least one of the following financial products: stocks and shares (excluding private equity holdings in one's own company), mutual funds, and financial options. To calculate a household's total financial wealth, we add the total value of the household's equity holdings to the value of its bonds, savings, and current account balances, savings certificates, insurance policies, growth funds, own private equity, and other savings. The two main dependent variables for our analyses are a dummy variable for investors who own equity, and the portfolio share of equity (i.e., the value of equity as a proportion of the household's total financial wealth). ${ }^{5}$

\subsection{Measuring internal economic locus of control}

Economic locus of control measures the extent to which a person believes that the economic outcomes in his or her life are due to personal effort (internal locus of control), as opposed to the result of luck, fate, or the intervention and influence of others (external locus of control). ${ }^{6}$ The DHS includes a block of 13 statements measuring internal economic locus of control that are a subset of the items from the validated scale of Furnham (1986). ${ }^{7}$ Each year between 2005 and 2007 and every two years afterward, these 13 statements were presented to survey respondents, who reported their agreement with each statement on a seven-point scale.

We construct a time-invariant measure of internal economic locus of control in the following way. We first reverse some items so that stronger agreement on all 13 statements increases with a stronger internal economic locus of control (i.e., scores are higher those who believe their economic outcomes are determined by their own efforts) and decreases with external economic locus of control (i.e., scores are lower for people who believe their economic outcomes are determined by factors out of their control). Second, we take the within-person mean of the 13 answers by year. Finally, for each person, we take the average of these means over all years, imputing this average over non-measured years. Averaging over time helps reduce measurement error, though it implicitly assumes that internal economic locus of control is stable over time. This stability assumption is supported by previous findings showing that locus of control is malleable during childhood (Elkins et al., 2020), that stabilizes during adolescence (Sherman, 1984), and that it is invariant to even strong changes in personal circumstances (Cobb-Clark and Schurer, 2013; Elkins et al., 2017). In our data, the stability assumption is supported by the high

\footnotetext{
${ }^{3}$ For a detailed description of the DHS, see Teppa et al. (2012) or visit the http://www.centerdata.nl/en/TopMenu/Projecten/DNB_household_study/CentERdata website at www.centerdata.nl.

${ }^{4}$ These are 41 percent of all available household head observations in our data and they are slightly less well-educated and earn less than the average household head in the DHS data. Nevertheless, our conclusions are not sensitive to accounting for this sample selectivity using Wooldridge (2007) inverse probability weighting estimator.

5 There is some subjectivity on how to classify equity based on these data. Our main results are robust to various redefinitions of equity and equity ownership. See also the results in Table 8 in Section 6 . All our monetary variables are measured in nominal Euros and we use a conversion rate of 2.2 Guilders per Euro for amounts measured before 2003, when the Euro was introduced as the measurement unit in the DHS.

${ }^{6}$ Even though both locus of control and economic locus of control were originally devised as multi-dimensional personality traits, it is common to operationalize them in an internal-external reduction, just as we do (Rotter, 1990). This is common practice in the literature (e.g., McInish, 1982; Coleman and DeLeire, 2003; Cebi, 2007; Cobb-Clark and Schurer, 2013).

7 See Appendix A for the complete list of the items used to construct measures of internal economic locus of control.
} 
rank-order year-to-year correlation in economic locus of control of 0.61 , similar to rank-order correlations of other psychological scales taken as time invariant in the literature (Roberts and DelVecchio, 2000). In addition, the null hypothesis of time-stability of internal economic locus of control cannot be rejected by the formal test developed by Salamanca (2018). We nevertheless relax this stability assumption in Section 6 .

The distribution of our internal economic locus of control scale is bell-shaped and spreads across the entire range of scores, with a mean of 4.6 and a variance of 0.48 . To ease the interpretation of our results, we standardize the scale by subtracting its sample mean and dividing it by its sample standard deviation.

\subsection{Measuring other covariates}

The DHS also includes six statements to measure respondents' preferences for risk in various financial decisions, and 12 statements from Strathman et al. (1994) measuring respondents' consideration of the future when making decisions. We use these statements to construct standardized indices for risk aversion (where higher scores indicate less willingness to take risks) and patience (where higher scores indicate more patience) similarly to the way we construct the internal economic locus of control index. ${ }^{8}$

We also include measures for an extensive set of individual and household socio-demographic characteristics that have been shown to be important for household investment decisions and could correlate with internal economic locus of control. These include characteristics of the household head, such as a quadratic polynomial for age, gender, education, marital status, and employment status, and household characteristics including household composition, household size, total household net income, and net household wealth. We also include year-by-region fixed effects to control for common shocks that affect all households in the same region and at the same time (such as yearly market returns, regional shocks to the housing market, and time-varying regional differences in the propensity to invest in equity). ${ }^{9}$

\section{Equity investments and internal locus of control}

Our approach is to estimate the relation between internal locus of control and investment in equity, and then to include additional predictors of investment in equity in our models that could serve as potential confounders or mechanisms for this relation. Our aim is to assess whether the included predictors explain away the effect of internal locus of control and therefore could have been confounding it. Adding potentially endogenous covariates, such as household income and wealth, could introduce bias in the coefficients of all control variables. However, standard omitted variable bias arguments (e.g., Stock and Watson, 2015, p.299-301) show that if any of these confounders captures the relation between economic locus of control and investment in equity, we can then conclude that the confounder can reasonably explain the relation. If the effect of internal locus of control remains, this is evidence that that the confounder, as measured, does not explain the relation between internal locus of control and investment in equity.

Table 1 reports ordinary least squares (OLS) coefficients of linear probability models relating the probability of owning equity under various specifications: first uncontrolled (Column 1), then after controlling for socio-demographic characteristics of the household head and the household (Column 2), after additionally controlling for risk aversion and patience (Column 3), and after additionally controlling for household income and wealth (Column 4). Throughout the remainder of the paper, we present and discuss regression coefficients in terms of average marginal effects, which we refer to as 'effects' for conciseness.

Column 1 shows that the effect of a one standard deviation increase in internal economic locus of control without controlling for any covariates is a 7.1 percentage point higher probability of owning equity. Controlling for socio-demographic characteristics (Column 2) reduces this effect by about 1.1 percentage points. More important, however, is whether there is an effect of internal locus of control on investment in equity over and beyond the effect of risk and time preferences. The emphasis on these two economic preferences is based on the many theoretical models that motivate their role in individual portfolio choice (e.g., Samuelson, 1969; Svensson, 1989). Previous studies have found strong correlations between locus of control these two preferences (McInish, 1982; Plunkett and Buehner, 2007). Column 3 adds measures of risk aversion and patience as covariates and shows that both have the expected effect on equity ownership and their effects are sizeable and precisely estimated. Controlling for economic preferences further decreases the effect of internal locus of control by 1.3 percentage points compared to Column 2, yet the effect of internal locus of control remains economically and statistically significant.

In Column 4 we add controls for household income and household wealth, both of which are related to locus of control (Cobb-Clark et al., 2016). Although these controls could be endogenous in our model, we include them because of their important role in the household portfolio literature (e.g., Hong et al., 2004; Guiso et al., 2008) and take this as our preferred

\footnotetext{
${ }^{8}$ See Appendix A for a complete list of the items used to construct measures of risk aversion, and patience. Warneryd (1996), Borghans and Golsteyn (2006) and Kapteyn and Teppa (2011) validate these statements as measures of risk aversion and patience. Consistent with previous findings, internal economic locus of control is negatively correlated to risk aversion and positively correlated to patience in our data (e.g., McInish, 1982; Plunkett and Buehner, 2007).

${ }^{9}$ Appendix Table B1 shows summary statistics for key variables in our main estimation sample. We impute missing covariate data with sample averages values and add dummies marking imputed data in our analyses. We never used imputed variation in the dependent variable or the key regressor for identifying our key estimates.
} 
Table 1

Equity ownership and internal economic locus of control.

\begin{tabular}{lllll}
\hline Dependent variable: Equity ownership & $(1)$ & $(2)$ & $(3)$ & $(4)$ \\
\hline Internal economic locus of control & $0.071^{* * *}$ & $0.060^{* * *}$ & $0.047^{* * * *}$ & $0.023^{* * *}$ \\
& $(0.008)$ & $(0.008)$ & $\begin{array}{l}(0.008) \\
(0.007)\end{array}$ \\
Risk aversion & & & $-0.154^{* * *}$ & $-0.141^{* * *}$ \\
& & & $(0.007)$ & $(0.007)$ \\
Patience & & & $0.045^{* * *}$ & $0.031^{* * *}$ \\
& & & $(0.007)$ & $(0.007)$ \\
Socio-demographic characteristics: & No & Yes & Yes & Yes \\
Income and wealth: & No & No & No & Yes \\
$R^{2}$ & 0.04 & 0.09 & 0.21 & 0.30 \\
Observations & 18,410 & 18,410 & 18,410 & 18,410 \\
Households & 3,151 & 3,151 & 3,151 & 3,151 \\
\hline
\end{tabular}

Linear probability model (OLS) coefficients. The dependent variable is a dummy that takes the value of one if the respondent household owns any equity. Socio-demographic characteristics include a quadratic polynomial for age and dummies for gender, education, marital status, household composition, household size, and household head occupation. Income and wealth include six dummies for net household income and three dummies for household wealth quartiles. All regressions include year-by-region fixed effects and additional dummies for imputed controls. Standard errors clustered at the household level in parenthesis. ${ }^{* * *}$ denotes significance at the $1 \%$ level, ${ }^{* *}$ at the $5 \%$ level, and ${ }^{*}$ at the $10 \%$ level.

Table 2

Portfolio allocation and internal economic locus of control.

\begin{tabular}{lllll}
\hline Dependent variable: Share of wealth invested in & $\begin{array}{l}\text { Equity } \\
(1)\end{array}$ & $\begin{array}{l}\text { Bonds } \\
(2)\end{array}$ & $\begin{array}{l}\text { Cash } \\
(3)\end{array}$ & $\begin{array}{l}\text { Other } \\
(4)\end{array}$ \\
\hline Internal economic locus of control & $\begin{array}{l}0.013^{* * *} \\
(0.004)\end{array}$ & $\begin{array}{l}0.001 \\
(0.001)\end{array}$ & $\begin{array}{l}-0.016^{* * *} \\
(0.004)\end{array}$ & $\begin{array}{l}0.001 \\
(0.002)\end{array}$ \\
Risk aversion & $-0.061^{* * *}$ & $-0.003^{* *}$ & $0.064^{* * *}$ & -0.001 \\
& $(0.003)$ & $(0.001)$ & $(0.004)$ & $(0.002)$ \\
Patience & $0.009^{* *}$ & 0.001 & $-0.011^{* * *}$ & 0.002 \\
& $(0.003)$ & $(0.001)$ & $(0.004)$ & $(0.003)$ \\
Socio-demographic characteristics: & Yes & Yes & Yes & Yes \\
Income and wealth: & Yes & Yes & Yes & Yes \\
Observations & 18,410 & 18,410 & 18,410 & 18,410 \\
Households & 3,151 & 3,151 & 3,151 & 3,151 \\
\hline
\end{tabular}

Average marginal effects of fractional response regressions. The dependent variables are the share of financial wealth invested in each asset class. Socio-demographic characteristics include a quadratic polynomial for age and dummies for gender, education, marital status, household composition, household size, and household head occupation. Income and wealth include six dummies for net household income and three dummies for household wealth quartiles. All regressions include year-by-region fixed effects and additional dummies for imputed controls. Standard errors clustered at the household level in parenthesis. ${ }^{* * *}$ denotes significance at the $1 \%$ level, ${ }^{* *}$ at the $5 \%$ level, and ${ }^{*}$ at the $10 \%$ level.

specification. Adding these controls results in a further reduction of the effect of internal locus of control by 2.4 percentage points. Nevertheless, the effect of internal locus of control remains economically important: A one standard deviation increase in internal economic locus of control (a 0.48 increase in the 7-point unstandardized scale) is associated with a 2.3 percentage point higher likelihood of owning equity. This marginal effect corresponds to an $8 \%$ increase in the probability to hold equity in our data. As reference, the effect of a one standard deviation increase in internal locus of control on equity ownership is slightly larger than the 1.5 percentage point effect of a one standard deviation increase in numeracy estimated by Christelis et al. (2010).

The availability of information on the value of equity as a share of each household's total financial wealth allows us to look not only at the impact of internal locus of control on equity investments at the extensive margins (i.e., the probability to own equity) but also at the intensive margin (i.e., the household portfolio share held in equity). To analyze this we estimate our preferred specification with the portfolio share of equity as the dependent variable. Because $71 \%$ of all households do not own equity, we estimate fractional regression models to account for the participation hurdle at zero. Table 2 shows that internal locus of control is positively related to the share of wealth invested in equity and negatively correlated to cash holdings. A one standard deviation increase in internal economic locus of control is associated with a 1.3 percentage point increase in the portfolio share of equity (Column 1), which amounts to $11 \%$ of the average share of equity for households in our data. This increase in equity comes entirely out of cash holdings (Column 3), not bond holdings or other asses.

Across all our analyzes the conclusions from models of equity ownership and of the portfolio share of equity are the same, so we focus on results for equity ownership for the remainder of the paper. 


\section{Subjective expectations as a mechanism}

In this section we try to explain our main findings by linking locus of control to two fundamental concepts in portfolio theory: expected return and expected risk. People with an internal economic locus of control could both expect a higher return on their investments and expect a lower variance on those same investments. Both mechanisms would induce people with an internal economic locus of control to own more equity.

Locus of control is hypothesized to be linked to perceived returns to investment in human capital by Coleman and DeLeire (2003). More recently, Caliendo et al. (2015) show that people with an internal locus of control search for jobs more because they perceive higher marginal returns to job search. In a related paper, they also show that locus of control affects people's decision to invest in training (Caliendo et al., 2020). Experimental evidence in McGee and McGee (2016) and Pinger et al. (2018) supports this idea. We think that a similar link between internal economic locus of control and subjective expected returns can explain our main findings: people with a stronger internal economic locus of control could invest more in equity because they expect higher returns on those investments.

A stronger internal locus of control can also be linked to perceiving a lower variance in outcomes. Following the study of Slovic (1992) on risk perception and its drivers, there was a surge of research on the relation between locus of control and risk perception, predominantly in the domain of health (e.g., Frijling et al., 2004; Jia et al., 2015). In other domains, people with an internal locus of control have been shown to perceive substantially less outcome risk (Simon et al., 2000; Kallmen, 2000; Sjöberg, 2000). We think that people with a more internal economic locus of control could also experience a sense of control over inherently stochastic processes, such as stock market returns, and thus underestimate the variance of returns to equity investments, which makes them more likely to invest in equity.

To investigate the empirical relevance of these two mechanisms, we use estimates of people's expectations of their investment return and risk. The ideal data to test this mechanism would include measures of people's subjective return and risk expectations on the market as well as on their own investment portfolios. Unfortunately, we have no access to separate measures on both such expectations, which limits the conclusions we can draw. Instead, we use respondents' individual estimates of the subjective return and risk of investing in 'blue chip' stocks (i.e., stocks of large, well-established and financially sound companies that have operated for many years).

These estimates were obtained by Hurd et al. (2011) for a subset of respondents of the 2004 and 2006 waves of the DHS based on people's answers to a sequence of eight questions. These questions elicited people's believed probabilities that an investment's gains or losses surpassed certain thresholds. The sequence of gain and loss questions starts by asking respondents to imagine that they unexpectedly received $€ 10,000$ from a rich relative and is thinking of putting the money into a mutual fund invested in 'blue chip' stocks (like those in the Amsterdam AEX stock market index). The wording of the first question in the gain sequence is: "Suppose you put the 10,000 Euro in the stock mutual fund and left it in for one year. What are the chances that you would make money where 0 means absolutely no chance and 100 means absolutely certain; that is what are the chances that in a year your investment would be worth more than 10,000 Euro?". The other questions in this sequence use a similar wording, with different numbers and adjusted to cover gain and loss sequences. Under parametric assumptions about the evolution of stock market returns, Hurd et al. (2011) recover estimates of each person's subjective return expectations and of the implied variance of these subjective investment returns. We use their estimates in this paper. ${ }^{10}$

Subjective expectation measures derived from the Hurd et al. (2011) questions could capture respondents' expectation on their own investments, on the market, or both. To the extent that respondents imagine eventually investing in the mutual fund they are 'thinking of putting the money into', as the questions ask, these return and risk expectations will capture respondents' expectations about their own mutual fund investments. Moreover, for respondents who would invest in a mutual fund that mirrors their current portfolio allocation these measures will capture their own investment portfolio expectations. If those portfolios closely track the AEX index, these measures would also coincide with respondents' market expectations. Finally, some respondents could have misread the question and answered based on their expectations of the AEX index rather than the mutual fund they would have thought of investing in. For those respondents the subjective expectations measure will solely capture market expectations and not expectation of their own investment portfolio.

In Table 3 we first show the effect of expected returns and expected risk (i.e., the expected standard deviation of returns) on internal locus of control individually, and then jointly. Because these expectations measures are specific to the year and the economic conditions in which they were asked, we limit our analyzes to the years 2004 and 2006 . Column 1 (Column 2) shows that expected returns (expected risk) have a positive (negative) relation to internal locus of control (Column 2 ). When we jointly include expected return and risk (Column 3), the coefficient on expected risk does not change size though it becomes less precisely estimated. The positive coefficient on expected return remains statistically and economically significant, and in unreported analyses we verify that it also remains significant even after controlling for investor experience. These findings link internal economic locus of control to subjective expectations and could mean that the effect of internal locus of control on equity investment can be understood from an individual perceived risk-return framework. ${ }^{11}$

\footnotetext{
10 We thank Joachim Winter for making these data available to us.

11 Appendix Appendix C presents further evidence of the link between internal locus of control and expected risk using information about investors in financial options in our data, and noting that for these assets expected risk as a mechanism makes a unique testable prediction.
} 
Table 3

Subjective return expectations, equity ownership, and internal economic locus of control.

\begin{tabular}{|c|c|c|c|c|c|}
\hline \multirow[t]{2}{*}{ Dependent variable: } & \multicolumn{3}{|c|}{ Internal economic locus of control } & \multicolumn{2}{|c|}{ Equity Ownership } \\
\hline & (1) & $(2)$ & (3) & $\overline{(4)}$ & (5) \\
\hline Internal economic locus of control & & & & $\begin{array}{l}0.029 * * * \\
(0.011)\end{array}$ & $\begin{array}{l}0.028^{* *} \\
(0.011)\end{array}$ \\
\hline Expected returns (in perc. points) & $\begin{array}{l}0.014^{* * *} \\
(0.005)\end{array}$ & & $\begin{array}{l}0.013^{* *} \\
(0.005)\end{array}$ & & $\begin{array}{l}0.004^{* *} \\
(0.002)\end{array}$ \\
\hline Expected S.D. of returns (in perc. points) & & $\begin{array}{l}-0.007^{* *} \\
(0.003)\end{array}$ & $\begin{array}{l}-0.004 \\
(0.004)\end{array}$ & & $\begin{array}{l}-0.001 \\
(0.002)\end{array}$ \\
\hline Socio-demographic characteristics: & Yes & Yes & Yes & Yes & Yes \\
\hline Risk aversion and patience: & Yes & Yes & Yes & Yes & Yes \\
\hline Income and wealth: & Yes & Yes & Yes & Yes & Yes \\
\hline$R^{2}$ & 0.23 & 0.22 & 0.23 & 0.29 & 0.29 \\
\hline Observations & 816 & 816 & 816 & 2,249 & 2,249 \\
\hline Households & 446 & 446 & 446 & 1,421 & 1,421 \\
\hline
\end{tabular}

OLS coefficients. The dependent variables are a time-constant measure of internal economic locus of control (Columns 1-3) and a dummy that takes the value of one if the respondent household owns any equity (Columns 4 and 5). Subjective expected return and return variance are the parametric estimates of alpha and sigma from Hurd et al. (2011) multiplied by 100 so they measure subjective expectations in percentage points. Columns 1-3 have fewer observations since we do not impute subjective expectations for these analyses. In Columns 4 and 5 we set missing values of subjective expectations to their sample mean, and we include an imputed value dummy in our estimation. Socio-demographic characteristics include a quadratic polynomial for age and dummies for gender, education, marital status, household composition, household size, and household head occupation. Income and wealth include six dummies for net household income and three dummies for household wealth quartiles. All regressions include year-by-region fixed effects and additional dummies for imputed controls. Standard errors clustered at the household level in parenthesis. *** denotes significance at the $1 \%$ level, ${ }^{* *}$ at the $5 \%$ level, and ${ }^{*}$ at the $10 \%$ level.

To test whether subjective expectations can explain the effect of internal locus of control, we add expected return and risk as covariates to our preferred equity ownership specification, imputing missing values for expectations. ${ }^{12}$ Column 4 of Table 3 replicates our preferred specification in this sub-sample as a benchmark. Column 5 shows that only expected returns have a significant effect on equity ownership, with a 1 percentage point increase in expected returns increasing the likelihood to own equity by 0.4 percentage points. More importantly, Column 5 shows that controlling for expected return and risk does not decrease the effect size or significance of internal locus of control on equity ownership. This evidence suggests that the link between internal economic locus of control and investment in equity does not operate through subjective expectations.

It is, however, natural to think that internal economic locus of control relates to people's expected investment returns on their own investments, yet there is a chance that our measures of subjective expectations are capturing solely people's expected market returns. If so, this would cast doubts over the appropriateness of our subjective expectations measures for the tests in this section. We argue above that this is unlikely, unless the majority of respondents misinterpreted the DHS questions used to construct these measures. To this argument, we add two reasons to believe that our measure of expectations is a good proxy for both market expectations and own-portfolio expectations. First Weber et al. (2013) show that people's subjective assessments of market return and risk correlate very highly with their assessments of the return and risk on their own investment portfolios. Their data shows a correlation between expected own-portfolio returns and expected market returns of 0.48 , and a correlation between expected own-portfolio risk and expected market risk of 0.64. These are relatively large correlations given the potential noise error in their measures. Second, Panel A in Appendix Table B2 shows that in our data on expected return and risk are equally good predictors of investment in mutual funds and in individual stocks. This could mean $i$ ) that people's stock investments and mutual fund investments are similar, ii) that their return and risk expectations on mutual funds and stocks are similar, or iii) that our subjective expectations measures capture expectations on mutual fund and stocks equally well. Our measure could also be picking up market expectations. But if this is the case, then those market expectations would have to match people's expectation on their mutual fund and stock investments to explain our findings. Either way, this evidence suggests that our subjective expectations measures are good proxies for people's own-portfolio expectations, even if they also measure their market expectations.

Overall, our conclusions in this section are limited by the fact that we cannot be certain that our subjective expectations measure are not just capturing aggregate market expectations. We show evidence suggesting this is unlikely to be the case, but reasonable doubts can still remain. We therefore view our analyses as providing only suggestive evidence that subjective expectations are not a mechanism driving the relation between internal locus of control and investment in equity. In the next section we press on to explore other explanations for this relation.

\footnotetext{
${ }_{12}$ Imputing expected return and risk values ensures the uncontrolled effect of internal locus of control on equity ownership is comparable to our main estimates in this subsample (Column 4). In Columns 4 and 5 we include a dummy for whether an imputation was used, ensuring that imputed variation does not identify any of the coefficients of interest. Multiple imputation methods for expected return and risk lead to the same conclusions.
} 


\section{Other potential explanations}

In this section we consider three alternative explanations, in the form of potential unobserved correlates, for our main results: i) financial literacy, ii) overconfidence, and iii) other personality traits. ${ }^{13}$

\subsection{Financial literacy}

Financial literacy plays an important role in portfolio choices by lowering the marginal (non-monetary) cost of investment, and it has been found to increase the likelihood of investing in the stock market (Van Rooij et al., 2011). Financial literacy is also likely to be related to economic locus of control, since becoming more financially literate can be a form of human capital accumulation driven by locus of control (Coleman and DeLeire, 2003). It is therefore important to consider financial literacy as a relevant correlate to establish the relation between internal economic locus of control and investment in equity.

Our data include a subjective self-assessment and an objective assessment of financial literacy. The subjective selfassessment is based on the survey question: "How knowledgeable do you consider yourself with respect to financial matters?", which respondents can answer using a four-point scale ranging from "not knowledgeable" to "very knowledgeable". This question is asked in the DHS from 2004 onward. We measure high subjective financial literacy with a dummy variable indicating people who assess themselves as "knowledgeable" or "very knowledgeable". The objective assessment uses a set of five basic literacy questions and 10 advanced literacy questions from Van Rooij et al. (2011). A typical basic literacy questions is "Suppose you had $€ 100$ in a savings account and the interest rate was $2 \%$ per year. After 5 years, how much do you think you would have in the account if you left the money to grow?" with possible answers “(i) More than $€$ 102; (ii) Exactly $€ 102$; (iii) Less than $€ 102$; (iv) Do not know; (v) Refuse to answer.". Advance literacy questions are substantially harder. We sum the scores on the basic and advanced literacy questions and, since the sumscores are strongly right-skewed, we measure high objective financial literacy with a dummy variable indicating household heads with a score higher than the median (11 out of 16 possible points). Internal economic locus of control is positively correlated with our measures of subjective $(\hat{r}=0.23)$ and objective $(\hat{r}=0.12)$ financial literacy. ${ }^{14}$

Table 4 shows the results of analyses in which we additionally control for financial literacy. Columns 1 and 2 add subjective and objective financial literacy to our preferred specification, one at the time. Both measures of financial literacy have positive effects on equity ownership, with high subjective (objective) literacy increasing the likelihood to invest in equity by 4.7 (9.8) percentage points. Subjective and objective financial literacy also have an effect on equity ownership independent of one another (Column 3). Yet we still find a large effect of internal locus of control on equity ownership after controlling for both types of financial literacy. This indicates that financial literacy is not driving our relation between internal economic locus of control and investment in equity.

We then explore the effect of internal locus of control for different levels of financial literacy. Column 4 presents the results of an estimation in which we interact internal locus of control with both indicators for high subjective and objective literacy. Internal locus of control has a 4.2 percentage point effect on equity ownership for low literacy households, but a much smaller and statistically insignificant 0.7 percentage point effect for high literacy households. The interactions with high subjective financial literacy imply similar differences in the effect of internal locus of control. Moreover, interactions between financial literacy and other covariates, unreported in the table, also reveal that risk aversion, patience, and key individual and household characteristics such as age and wealth, have stronger effects on equity ownership for high literacy households compared to low literacy households.

The results in Column 4 of Table 4 are consistent with a behavioral model of personality in portfolio choice where factors at the core of traditional household portfolio models-such as risk aversion, patience, and wealth-play an important role for the investment decisions of high financial literacy households, whereas personality plays a comparatively more important role on the investment decisions of financially-unsophisticated ones.

If part of financial literacy is having relevant financial information, these results are also consistent with McGee and McGee (2016) who find in a laboratory experiment that internal locus of control no longer predicts job search behavior if participants received objective information about returns to search effort. They are also consistent with Pinger et al. (2018) who find in another lab experiment that participants with an internal locus of control overreact to chance outcomes and, as a result, perform worse in the experiment. In view of these two studies, our own findings point to the hypothesis that the effect of internal locus of control operates through people's expected return and risk, which we discussed on Section 4, and that more financially-literate people are less reliant on these subjective expectations.

\footnotetext{
13 Most of the measures we explore in this section are only available for selected years in the DHS. To maximize power, we assume all these measures are time-constant and impute their time-averages for non-response years, just as we do for internal locus of control. None of our conclusions change if we relax this assumption and use time-varying measures of financial literacy, overconfidence or personality as regressors.

14 The complete set of questions for objective financial literacy can be found in the study of Van Rooij et al. (2011, pp. 452-454) and are asked in 2004. We thank Maarten van Rooij for making these data available to us.
} 
Table 4

Equity ownership, financial literacy, and internal economic locus of control.

\begin{tabular}{|c|c|c|c|c|}
\hline Dependent variable: Equity ownership & (1) & $(2)$ & (3) & (4) \\
\hline \multicolumn{5}{|l|}{ Main effects: } \\
\hline Internal economic locus of control & $\begin{array}{l}0.018^{* *} \\
(0.007)\end{array}$ & $\begin{array}{l}0.018^{* * *} \\
(0.007)\end{array}$ & $\begin{array}{l}0.014^{* *} \\
(0.007)\end{array}$ & $\begin{array}{l}0.042^{* * *} \\
(0.013)\end{array}$ \\
\hline High subjective financial literacy & $\begin{array}{l}0.047^{* * *} \\
(0.014)\end{array}$ & & $\begin{array}{l}0.043^{* * *} \\
(0.014)\end{array}$ & $\begin{array}{l}0.016 \\
(0.078)\end{array}$ \\
\hline High objective financial literacy & & $\begin{array}{l}0.098^{* * *} \\
(0.020)\end{array}$ & $\begin{array}{l}0.096 * * * \\
(0.020)\end{array}$ & $\begin{array}{l}0.103 \\
(0.117)\end{array}$ \\
\hline \multicolumn{5}{|l|}{ Interactions with locus of control: } \\
\hline High subjective financial literacy & & & & $\begin{array}{l}-0.021 \\
(0.014)\end{array}$ \\
\hline High objective financial literacy & & & & $\begin{array}{l}-0.035^{*} \\
(0.020)\end{array}$ \\
\hline Socio-demographic characteristics: & Yes & Yes & Yes & Yes \\
\hline Risk aversion and patience: & Yes & Yes & Yes & Yes \\
\hline Income and wealth: & Yes & Yes & Yes & Yes \\
\hline$R^{2}$ & 0.30 & 0.30 & 0.31 & 0.33 \\
\hline Observations & 18,410 & 18,410 & 18,410 & 18,410 \\
\hline Households & 3,151 & 3,151 & 3,151 & 3,151 \\
\hline
\end{tabular}

Linear probability model (OLS) coefficients. The dependent variable is a dummy that takes the value of one if the respondent household owns any equity. High subjective financial literacy is a dummy for whether the respondent answered in the top two categories of the subjective financial literacy survey question. High objective financial literacy is a dummy for whether the respondent scored above the median (11 out of 16 points) in a financial literacy quiz. Socio-demographic characteristics include a quadratic polynomial for age and dummies for gender, education, marital status, household composition, household size, and household head occupation. Income and wealth include six dummies for net household income and three dummies for household wealth quartiles. All regressions include year-byregion fixed effects and additional dummies for imputed controls. Standard errors clustered at the household level in parenthesis. ${ }^{* * *}$ denotes significance at the $1 \%$ level, ${ }^{* *}$ at the $5 \%$ level, and * at the $10 \%$ level.

\subsection{Overconfidence}

The second potential confounder we consider is overconfidence. Overconfidence holds an important place in the behavioral finance literature, with the seminal papers of both Barber and Odean (2001) and Malmendier and Tate (2005) showing that overconfidence is significantly related to investment decisions. Although they are fundamentally different concepts, internal economic locus of control could be related to overconfidence, making overconfidence another relevant correlate in our analyses. ${ }^{15}$

We construct our measure of overconfidence in two stages. First, we regress our measure of subjective financial literacy on a quadratic polynomial of objective financial literacy and obtain the predicted regression residuals. These residuals capture variation in subjective financial literacy over and above measured objective literacy, measuring overconfidence in the spirit of Puri and Robinson (2007). Second, we take the time-constant average of the residual of this regression for each respondent as our measure of overconfidence in our analyses. ${ }^{16}$

Column 1 of Table 5 documents the relation between our overconfidence measure and equity ownership. As expected, overconfidence has a strong positive effect on investment in equity. Controlling for overconfidence, however, does not decrease the effect of internal locus of control on equity ownership (Columns 2 through 5). In fact, while the effect of overconfidence is explained away by the inclusion of risk and time preferences (Columns 3 and 4), the effect of internal locus of control remains economically and statistically significant. We thus conclude that overconfidence cannot explain our main results. ${ }^{17}$

\footnotetext{
15 Internal locus of control captures the extent to which individuals believe they are in control of their own future. The concept is silent, however, about which actions one must undertake to achieve this control. In our setting, this means that internal economic locus of control cannot predict whether an "in-control investor" would be more active or passive in the stock market. This is one of the key differences between the effects of internal economic locus of control and overconfidence in an investor model.

${ }^{16}$ Appendix Fig. B1 shows that the relation between subjective and objective literacy is well approximated by a quadratic fit. The substantial heterogeneity across individuals in this fit identifies our measure of overconfidence.

17 We construct a second test for overconfidence based on Gervais and Odean (2001), who observe that overconfidence should decrease with investor experience. If economic locus of control is simply a proxy for overconfidence, it should thus also decrease with experience. The results presented in Appendix Table B3 show that this is not the case in our data.
} 
Table 5

Equity ownership, overconfidence, and internal economic locus of control.

\begin{tabular}{llllll}
\hline Dependent variable: Equity ownership & $(1)$ & $(2)$ & $(3)$ & $(4)$ & $(5)$ \\
\hline Internal economic locus of control & & $0.068^{* * *}$ & $0.056^{* * *}$ & $0.046^{* * *}$ & $0.022^{* * *}$ \\
& & $(0.008)$ & $(0.008)$ & $(0.008)$ & $(0.007)$ \\
Overconfidence & $0.033^{* * *}$ & $0.023^{* *}$ & $0.025^{* * *}$ & 0.005 & 0.002 \\
& $(0.010)$ & $(0.009)$ & $(0.009)$ & $(0.008)$ & $(0.007)$ \\
Socio-demographic characteristics: & No & No & Yes & Yes & Yes \\
Risk aversion and patience: & No & No & No & Yes & Yes \\
Income and wealth: & No & No & No & No & Yes \\
$R^{2}$ & 0.02 & 0.05 & 0.10 & 0.22 & 0.31 \\
Observations & 18,410 & 18,410 & 18,410 & 18,410 & 18,410 \\
Households & 3,151 & 3,151 & 3,151 & 3,151 & 3,151
\end{tabular}

Linear probability model (OLS) coefficients. The dependent variable is a dummy that takes the value of one if the respondent household owns any equity. Overconfidence is measured as the individual timeaverage of the residual of the following regression fit: Subjective Literacy $=-0.076$ bjective Literacy + 0.006 bjective Literacy ${ }^{2}$, ran with 8,620 household-year observations for 1,328 households in the 20042015 period. Socio-demographic characteristics include a quadratic polynomial for age and dummies for gender, education, marital status, household composition, household size, and household head occupation. Income and wealth include six dummies for net household income and three dummies for household wealth quartiles. All regressions include year-by-region fixed effects and additional dummies for imputed controls. Standard errors clustered at the household level in parenthesis. ${ }^{* * *}$ denotes significance at the $1 \%$ level, ${ }^{*}$ at the $5 \%$ level, and * at the $10 \%$ level.

\subsection{Optimism, trust, and other personality traits}

There are at least three other relevant correlates for the relation between internal economic locus of control and equity investment: optimism, trust, and the Big Five personality traits. All three have been shown to be related to investment in equity (Puri and Robinson, 2007; Guiso et al., 2008; Agnew and Szykman, 2005) and many of them have a positive correlation with locus of control (e.g., Guarnera and Williams, 1987; Hoorens and Buunk, 1993; Albanese et al., 2013). We therefore test if the effect of internal locus of control on equity ownership is not simply reflecting unobserved differences in these potential correlates, and present these results in Table 6.

To measure optimism, we use the index constructed from the Life Orientation Test, revisited (LOT-R) of Scheier et al. (1994, p.1073). This standard and validated measure of optimism is also used by Guiso et al. (2008) in household portfolio analyses of the DHS. Column 1 of Panel A in Table 6 shows that effect of optimism on equity ownership is weak. Columns 2 to 5 further show that including optimism as a covariate does not affect the effect of internal economic locus of control.

To measure trust, we use a question introduced in the DHS that follows the World Values Survey measure of trust: "Generally speaking, would you say that most people can be trusted or that you have to be very careful in dealing with people?". Following Guiso et al. (2008), we code trust as a dummy for answering that "most people can be trusted", as opposed to answering "you can never be too careful when dealing with others". Column 1 of Panel B in Table 6 shows that trust has a positive effect on equity ownership. However, controlling for trust does not decrease the effect of internal locus of control (Columns 2 through 5). ${ }^{18}$

To measure other personality traits, we use a 50-item question battery of the Big Five. The Big Five (Openness, Conscientiousness, Extraversion, Agreeableness, and Neuroticism) are a comprehensive, data-driven inventory of five overarching personality traits (Goldberg, 1993). ${ }^{19}$ The Big Five have been the most commonly used tool to measure personality for decades and there is widespread agreement within personality research about the five underlying dimensions and their content (Barrick et al., 2003; Durand et al., 2008). Each dimension of the Big Five is measured through 10 items from Goldberg (1999), which we aggregate in a standardized scale analogous to the way we aggregate the locus of control items. Columns 1 through 5 of Panel $C$ in Table 6 shows that the Big Five have some effects on equity ownership, although these effects vary across specifications. However, the effect of internal locus of control is yet again unaffected including the Big Five as covariates.

In sum, Tables 4 through 6 show that the main effect of internal locus of control on equity ownership is unlikely to be driven by correlated subjective or objective financial literacy, overconfidence, optimism, trust, or any of the Big Five personality traits. We therefore cautiously conclude that the relation between economic locus of control and investment in equity stands on its own and is not reflecting the main behavioral drivers explored in the large literature on household portfolio choice. This is the main finding on this paper, and in the next section we further show it to be robust to a number of specification checks and to relaxing various assumptions we have made along the way. ${ }^{20}$

\footnotetext{
18 We thank Luigi Guiso for making the data for optimism and trust available to us. These questions are asked in 2003.

19 The complete 50-item Big Five questionnaire is included in years 2005, 2009, 2013, and 2014.

20 One potential relevant correlate we cannot analyze is self-esteem. Judge et al. (2002) suggest a possible mild correlation between self-esteem and the standard measures of locus of control, and self-esteem is correlated with owning financial assets (Chatterjee et al., 2009). Our data do not include a measure of self-esteem, yet the items measuring internal economic locus of control differ sufficiently from the classical measures of self-esteem (the Rosenberg
} 
Table 6

Equity ownership, optimism, trust, personality, and internal economic locus of control.

\begin{tabular}{|c|c|c|c|c|c|}
\hline Dependent variable: Equity ownership & (1) & $(2)$ & (3) & (4) & (5) \\
\hline \multicolumn{6}{|c|}{ Panel A } \\
\hline Internal economic locus of control & & $\begin{array}{l}0.071^{* * *} \\
(0.008)\end{array}$ & $\begin{array}{l}0.058^{* * *} \\
(0.008)\end{array}$ & $\begin{array}{l}0.044^{* * *} \\
(0.008)\end{array}$ & $\begin{array}{l}0.021^{* * *} \\
(0.007)\end{array}$ \\
\hline Optimism & $\begin{array}{l}0.017^{*} \\
(0.009)\end{array}$ & $\begin{array}{l}0.004 \\
(0.009)\end{array}$ & $\begin{array}{l}0.006 \\
(0.009)\end{array}$ & $\begin{array}{l}0.012 \\
(0.008)\end{array}$ & $\begin{array}{l}0.007 \\
(0.007)\end{array}$ \\
\hline$R^{2}$ & 0.02 & 0.04 & 0.09 & 0.21 & 0.30 \\
\hline \multicolumn{6}{|c|}{ Panel B } \\
\hline Internal economic locus of control & & $\begin{array}{l}0.071^{* * *} \\
(0.008)\end{array}$ & $\begin{array}{l}0.059^{* * *} \\
(0.008)\end{array}$ & $\begin{array}{l}0.046^{* * *} \\
(0.008)\end{array}$ & $\begin{array}{l}0.023^{* * *} \\
(0.007)\end{array}$ \\
\hline Trust & $\begin{array}{l}0.101^{* * *} \\
(0.027)\end{array}$ & $\begin{array}{l}0.095^{* * *} \\
(0.026)\end{array}$ & $\begin{array}{l}0.067^{* * *} \\
(0.026)\end{array}$ & $\begin{array}{l}0.046^{* *} \\
(0.023)\end{array}$ & $\begin{array}{l}0.034^{*} \\
(0.020)\end{array}$ \\
\hline$R^{2}$ & 0.02 & 0.05 & 0.10 & 0.21 & 0.30 \\
\hline \multicolumn{6}{|c|}{ Panel C } \\
\hline Internal economic locus of control & & $\begin{array}{l}0.076^{* * *} \\
(0.009)\end{array}$ & $\begin{array}{l}0.070^{* * *} \\
(0.009)\end{array}$ & $\begin{array}{l}0.051^{* * *} \\
(0.008)\end{array}$ & $\begin{array}{l}0.024^{* * *} \\
(0.007)\end{array}$ \\
\hline Openness & $\begin{array}{l}0.033^{* * *} \\
(0.010)\end{array}$ & $\begin{array}{l}0.017^{*} \\
(0.010)\end{array}$ & $\begin{array}{l}0.005 \\
(0.010)\end{array}$ & $\begin{array}{l}-0.002 \\
(0.009)\end{array}$ & $\begin{array}{l}0.004 \\
(0.008)\end{array}$ \\
\hline Conscientiousness & $\begin{array}{l}-0.010 \\
(0.009)\end{array}$ & $\begin{array}{l}-0.023^{* * *} \\
(0.009)\end{array}$ & $\begin{array}{l}-0.021^{* *} \\
(0.009)\end{array}$ & $\begin{array}{l}-0.014^{*} \\
(0.008)\end{array}$ & $\begin{array}{l}-0.015^{* *} \\
(0.007)\end{array}$ \\
\hline Extraversion & $\begin{array}{l}-0.008 \\
(0.010)\end{array}$ & $\begin{array}{l}-0.009 \\
(0.010)\end{array}$ & $\begin{array}{l}-0.005 \\
(0.009)\end{array}$ & $\begin{array}{l}-0.025^{* * *} \\
(0.008)\end{array}$ & $\begin{array}{l}-0.019^{\text {**** }} \\
(0.007)\end{array}$ \\
\hline Agreeableness & $\begin{array}{l}-0.032^{* * *} \\
(0.010)\end{array}$ & $\begin{array}{l}-0.033^{* * *} \\
(0.010)\end{array}$ & $\begin{array}{l}-0.013 \\
(0.010)\end{array}$ & $\begin{array}{l}0.008 \\
(0.009)\end{array}$ & $\begin{array}{l}0.015^{*} \\
(0.008)\end{array}$ \\
\hline Neuroticism & $\begin{array}{l}-0.025^{* * *} \\
(0.009)\end{array}$ & $\begin{array}{l}-0.015^{*} \\
(0.009)\end{array}$ & $\begin{array}{l}0.011 \\
(0.009)\end{array}$ & $\begin{array}{l}-0.006 \\
(0.008)\end{array}$ & $\begin{array}{l}-0.003 \\
(0.007)\end{array}$ \\
\hline$R^{2}$ & 0.03 & 0.05 & 0.10 & 0.21 & 0.30 \\
\hline Socio-demographic characteristics: & No & No & Yes & Yes & Yes \\
\hline Risk aversion and patience: & No & No & No & Yes & Yes \\
\hline Income and wealth: & No & No & No & No & Yes \\
\hline Observations & 18,410 & 18,410 & 18,410 & 18,410 & 18,410 \\
\hline Households & 3,151 & 3,151 & 3,151 & 3,151 & 3,151 \\
\hline
\end{tabular}

Linear probability models coefficients (OLS). The dependent variable is a dummy that takes the value of one if the respondent household owns any equity. Optimism is measured via the 24-point scale LOT-R. Trust is measured via a dummy for trusting others as asked in the World Value Survey. The Big Five are measured in standardized scales constructed using the 50-item scales in Goldberg (1992). Socio-demographic characteristics include a quadratic polynomial for age and dummies for gender, education, marital status, household composition, household size, and household head occupation. Income and wealth include six dummies for net household income and three dummies for household wealth quartiles. All regressions include year-by-region fixed effects and additional dummies for imputed controls. Standard errors clustered at the household level in parenthesis. ${ }^{* * *}$ denotes significance at the $1 \%$ level, ${ }^{* *}$ at the $5 \%$ level, and ${ }^{*}$ at the $10 \%$ level.

\section{Further specification analyses}

In this section we present three important extensions to our results so far. First, we show that relaxing the assumption that internal locus of control and many of our other key measures are time-constant does not alter our results. Second, we explore the effect of internal locus of control on different types of equity, providing further insights into the nature of its effects. And third, we show that our conclusions hold after accounting for measurement error in internal locus of control and its potential correlates.

Throughout this paper, we have assumed for simplicity that internal economic locus of control as well as risk aversion and patience are stable within adult individuals, an assumption supported by previous studies (Sherman, 1984; Cobb-Clark and Schurer, 2012; 2013; Salamanca, 2018). In Table 7 we show the results of various models that support our hypothesis of stability, and show that relaxing this assumption does not affect our main conclusions. These analyses are all aimed at providing evidence that the effect of internal economic locus of control on investment in equity is Granger-causal (i.e., at dispelling concerns about the causality running from equity investment onto internal economic locus of control).

We first estimate two models with time-invariant internal locus of control, risk aversion, and patience with some restrictions aimed at reducing concerns about their time-stability. Column 1 of Table 7 shows very similar results to our main specification in a sub-sample with household heads aged 30 or more. People over this age are considered to have stable

scale) to alleviate concerns on this unobservable correlate. Furthermore, self-esteem cannot explain our results in Section 4 or Appendix Tables B2, B3, and Appendix C. 
Table 7

Equity ownership and alternative measures of internal economic locus of control.

\begin{tabular}{|c|c|c|c|c|c|}
\hline \multirow[b]{2}{*}{ Dependent variable: Equity ownership } & \multicolumn{3}{|c|}{ Time-invariant indices } & \multicolumn{2}{|c|}{ Time-varying indices } \\
\hline & $\begin{array}{l}>30 \text { years old } \\
\text { (1) }\end{array}$ & $\begin{array}{l}\text { First measure } \\
(2)\end{array}$ & $\begin{array}{l}\text { Std. mean } \\
(3)\end{array}$ & $\begin{array}{l}\text { Factor analyses } \\
\text { (4) }\end{array}$ & $\begin{array}{l}\text { Lagged reg. } \\
\text { (5) }\end{array}$ \\
\hline Internal economic locus of control & $\begin{array}{l}0.022^{* * *} \\
(0.007)\end{array}$ & $\begin{array}{l}0.026^{* * *} \\
(0.007)\end{array}$ & $\begin{array}{l}0.033^{* * *} \\
(0.008)\end{array}$ & $\begin{array}{l}0.035^{* * *} \\
(0.009)\end{array}$ & $\begin{array}{l}0.032^{* * *} \\
(0.009)\end{array}$ \\
\hline Risk aversion & $\begin{array}{l}-0.142^{* * *} \\
(0.007)\end{array}$ & $\begin{array}{l}-0.101^{* * *} \\
(0.007)\end{array}$ & $\begin{array}{l}-0.124^{* * *} \\
(0.008)\end{array}$ & $\begin{array}{l}-0.148^{* * *} \\
(0.009)\end{array}$ & $\begin{array}{l}-0.107^{* * *} \\
(0.009)\end{array}$ \\
\hline Patience & $\begin{array}{l}0.032^{* * *} \\
(0.007)\end{array}$ & $\begin{array}{l}0.022 * * * \\
(0.007)\end{array}$ & $\begin{array}{l}0.035^{* * *} \\
(0.008)\end{array}$ & $\begin{array}{l}0.035^{* * *} \\
(0.008)\end{array}$ & $\begin{array}{l}0.022^{* *} \\
(0.009)\end{array}$ \\
\hline Socio-demographic characteristics: & Yes & Yes & Yes & Yes & Yes \\
\hline Income and wealth: & Yes & Yes & Yes & Yes & Yes \\
\hline$R^{2}$ & 0.30 & 0.26 & 0.27 & 0.27 & 0.24 \\
\hline Observations & 17,404 & 18,410 & 5,298 & 5,281 & 3,788 \\
\hline Households & 2,935 & 3,152 & 2,450 & 2,448 & 1,629 \\
\hline
\end{tabular}

Linear probability models (OLS). The dependent variable is a dummy that takes the value of one if the respondent household owns any equity. Column headers mark differences in the estimation sample (Column 1) and the construction of internal economic locus of control, risk aversion, and patience (Columns 2-5). > 30 years old: Sample restricted to household heads older than 30. First measure: Standardized mean of items when they were first measured in the DHS. Std. mean: Time-varying within-person means of items as scales. Factor analyses: First predicted factors derived from confirmatory factor analyses of each item set. Lagged reg.: One-year lags of time-varying within-person mean scales and all other covariates. Sociodemographic characteristics include a quadratic polynomial for age and dummies for gender, education, marital status, household composition, household size, and household head occupation. Income and wealth include six dummies for net household income and three dummies for household wealth quartiles. All regressions include year-by-region fixed effects and additional dummies for imputed controls. Standard errors clustered at the household level in parenthesis. ${ }^{* * *}$ denotes significance at the $1 \%$ level, ${ }^{* *}$ at the $5 \%$ level, and ${ }^{*}$ at the $10 \%$ level.

Table 8

Ownership of different types of financial assets and internal economic locus of control.

\begin{tabular}{lllll}
\hline Dependent variable: Ownership of & $\begin{array}{l}\text { Stocks } \\
(1)\end{array}$ & $\begin{array}{l}\text { Mutual funds } \\
(2)\end{array}$ & $\begin{array}{l}\text { Bonds } \\
(3)\end{array}$ & $\begin{array}{l}\text { Other assets } \\
(4)\end{array}$ \\
\hline Internal economic locus of control & $\begin{array}{l}0.022^{* * *} \\
(0.006)\end{array}$ & $\begin{array}{l}0.008 \\
(0.007)\end{array}$ & $\begin{array}{l}0.006^{*} \\
(0.003)\end{array}$ & $\begin{array}{l}0.002 \\
(0.002)\end{array}$ \\
Risk aversion & $-0.103^{* * *}$ & $-0.101^{* * *}$ & $-0.019^{* * *}$ & $-0.006^{* *}$ \\
& $(0.007)$ & $(0.007)$ & $(0.004)$ & $(0.002)$ \\
Patience & $0.010^{*}$ & $0.028^{* * *}$ & 0.005 & $0.005^{* *}$ \\
& $(0.006)$ & $(0.006)$ & $(0.003)$ & $(0.002)$ \\
Socio-demographic characteristics: & Yes & Yes & Yes & Yes \\
Income and wealth: & Yes & Yes & Yes & Yes \\
$R^{2}$ & 0.21 & 0.22 & 0.08 & 0.02 \\
Observations & 18,410 & 18,410 & 18,410 & 18,410 \\
Households & 3,151 & 3,151 & 3,151 & 3,151
\end{tabular}

Linear probability model (OLS) coefficients. The dependent variable is a dummy that takes the value of one if the respondent household owns any of the assets marked above. Other assets include mostly financial real estate. Socio-demographic characteristics include a quadratic polynomial for age and dummies for gender, education, marital status, household composition, household size, and household head occupation. Income and wealth include six dummies for net household income and three dummies for household wealth quartiles. All regressions include year-by-region fixed effects and additional dummies for imputed controls. Standard errors clustered at the household level in parenthesis. ${ }^{* * *}$ denotes significance at the $1 \%$ level, ${ }^{* *}$ at the $5 \%$ level, and ${ }^{*}$ at the $10 \%$ level

personality traits (e.g., Donnellan and Lucas, 2008). Column 2 shows that taking the first measure of internal locus of control and risk and time preferences (and therefore minimizing the chance of reverse causality) yields near-identical results too.

We then consider three analyses with time-varying measures of internal locus of control, risk aversion, and patience. Columns 3 through 5 of Table 7 show that using time-varying within-person averages (Column 3), the first factor of confirmatory factor analyses (Column 4), and lagged time-varying measures of all the main regressors (Column 5) again yield very similar results to our main specification. We are thus reassured that our main findings are do not depend on the assumption that personality and preferences are stable over time, and are also not driven by reverse causality.

Second, we investigate the extent to which our findings hold for various sub-components of equity. As discussed in Section 2, our measure of equity includes stocks, mutual funds, and options, of which the former two are by far the leading components. We thus analyze these two components separately, and compare them to investments in bonds and in other financial assets (which are largely financial real estate).

Table 8 shows that the effect of internal locus of control on equity ownership is mainly driven by its effect on stock ownership (Column 1). Internal locus of control has no effect on mutual funds ownership and on ownership of other assets 
(Columns 2 and 4) and only a small negative effect on bond ownership (Column 3). Stocks are likely the riskier equity subclass we analyze; they tend to have the most salient risk profile and the largest idiosyncratic return variation. Stocks are also traditionally traded by speculators trying to 'beat the market' by building their own portfolios, consistent with a belief that their own investment choices will result in higher returns. The results in Table 8 are thus consistent with a relation between internal economic locus of control and subjective expectations of people's own stock portfolios. One could then wonder if our subjective return measure, which measures expectations on mutual fund returns, is adequate for testing a relation that is driven mainly by stock ownership. In Section 4 we argue why this is the case and, as supporting evidence, Panel A of Appendix Table B2 shows that subjective expectations predict stock ownership as well as they predict mutual fund ownership. Panels B and C then show that subjective expectations cannot explain the effect of internal locus of control on stock investments either. To the extent that our measure of subjective expectations can capture expectations on stock investments, we therefore take this as evidence that subjective expectations do not explain the effect of internal locus of control on stock ownership either.

Finally, we investigate the extent to which measurement error could have hampered our analyses. Our use of multiitem scales as regressors minimizes, yet does not eliminate, the influence of measurement error on our estimates. The remaining measurement error could attenuate our estimated effect of internal locus of control on equity ownership but, more importantly, it could also weaken our ability to explain this effect away by controlling for potential correlates. Gillen et al. (2019) show that ignoring measurement error in key control variables can dramatically alter the results of a study. They also develop the Obviously Related Instrumental variable (ORIV) estimator, a convenient way to account for measurement error in regressors and outcomes which can be implemented when there are multiple measures of each imperfectly-measured variable.

We produce Gillen et al.'s ORIV estimator of the relation between internal locus of control and equity ownership controlling for measurement-error-corrected versions of the following variables: risk aversion, patience, subjective expectations, subjective financial literacy, and the Big Five personality traits. These are all the constructs for which we have multiple measures over time and can therefore obtain estimates corrected for measurement error. Our ORIV uses first-time measures of the scales of economic locus of control, risk aversion, patience, and the Big Five, each as an instrument for its corresponding scale in subsequent years. Our ORIV also uses the first-time measure of subjective financial literacy in its original 1-to-4 scale as instrument for subsequent measures of subjective financial literacy. Finally, for subjective market return and risk expectations our ORIV uses 2004 measures as instruments for 2006 expectations, and 2006 measures as instruments for 2004 expectations. These are valid instruments under the assumption that year-to-year variation in subjective expectations are captured by our other control variables-notably by our year-by-region fixed effects.

Appendix Table B4 shows that most of our measures still contained substantial measurement error. However, the results also show that the effect of internal locus of control on equity ownership remains statistically and economically and significant even after controlling for measurement error-corrected confounders.

\section{Conclusions}

We show that internal economic locus of control is an important determinant of investment in equity. Locus of control relates to both the decision to own equity and the share of equity in household's portfolios. These relations are economically meaningful: a one-standard deviation increase in internal locus of control relates to an eight percent increase in the probability to own equity and an 11 percent increase in the share of household wealth invested in equity. These relations hold even after accounting for differences in risk and time preferences, and other main confounders identified in the household portfolio choice literature. After ruling out all the main alternative explanations for these results, including reverse causality, we still find a strong and robust relation between internal locus of control and investment in equity. Unless there is a strong enough source of unobserved heterogeneity that has not yet been explored in the literature, we are inclined to cautiously view our estimates as causal-or rather, as causal as relationships between personality traits and behaviors can be.

We have gone further by trying to empirically link locus of control to investment in equity through subjective return and risk expectations. We argue that subjective expectations of higher returns and lower risk are potential mechanisms behind the relation between internal locus of control and investments in equity. This mechanism is plausible: internal locus of control is positively-related to measures of expected returns and negatively-related to expected risk. However, these subjective expectation measures cannot explain the relation between internal locus of control and investment in equity. One caveat for interpreting this evidence, though, is that our measures of subjective expectations could be capturing people's expectations on market returns rather than on their own investment portfolios. Our data does not allow us to directly test whether this is the case, though the high correlations between people's market expectations and own-portfolio expectations in previous studies, as well as evidence in our own data, suggest that our measures may be proxying for both market and own-portfolio return and risk expectations. Nevertheless, we cautiously view our evidence on subjective expectations as suggestive and hope future research can provide a more definitive test.

We also find that the relation between internal economic locus of control and equity investment holds only for households with low financial literacy. This result suggests that locus of control relates to investment behavior in much the same way as various other behavioral biases and investor sentiment regularities-it weakens for savvy investors. More work exploring the differences in the determinants of investment behavior between financially knowledgeable and unknowledgeable people will surely yield important insights on this topic. 
Our results provide a comprehensive description of a strong relation between locus of control and investment behavior. And, even though we cannot unambiguously determine the underlying mechanisms behind this relation, we provide comprehensive evidence that most mechanisms one would have considered a priori are in fact not likely to be driving it. Our results can therefore guide future efforts to understand the link between personality and investment decision-making.

\section{Declaration of Competing Interest}

The authors declare that they have no known competing financial interests or personal relationships that could have appeared to influence the work reported in this paper.

\section{Appendix A. Items Measuring Internal Economic Locus of Control, Financial Risk Aversion, and Patience}

\section{Internal economic locus of control items}

Please indicate for the following statements to which extent you agree or disagree, where 1 means you completely disagree and 7 means you completely agree:

1. Saving and careful investing are a key factor in becoming rich.

2. Whether or not I get to become wealthy depends mostly on my ability.

3. In the long run, people who take very good care of their finances stay wealthy.

4. If I become poor, it's usually my own fault.

5. I am usually able to protect my personal interests.

6. When I get what I want, it's usually because I worked hard for it.

7. My life is determined by my own actions.

8. There is little one can do to prevent poverty. (reverse coded)

9. Becoming rich has nothing to do with luck.

10. Regarding money, there isn't much you can do for yourself when you are poor. (reverse coded)

11. It's not always wise for me to save, because many things turn out to be a matter of good or bad fortune. (reverse coded)

12. It's chiefly a matter of fate whether I become rich or poor. (reverse coded)

13. Only those who inherit or win money can possibly become rich. (reverse coded)

\section{Financial risk aversion items}

The following statements concern saving and taking risks. Please indicate on a scale from 1 to 7 to what extent you agree with the following statements, where 1 indicates completely disagree and 7 indicates completely agree:

1. I think it is more important to have safe investments and guaranteed returns, than to take a risk to have a chance to get the highest possible returns.

2. I would never consider investments in shares because I find this too risky.

3. If I think an investment will be profitable, I am prepared to borrow money to make this investment. (reverse coded)

4. I want to be certain that my investments are safe.

5. I get more and more convinced that I should take greater financial risks to improve my financial position. (reverse coded)

6. I am prepared to take the risk of losing money, when there is also a chance to gain money. (reverse coded)

\section{Patience items}

The following statements are about the future. Please indicate on a scale from 1 to 7 to what extent you agree with the following statements, where 1 indicates completely disagree and 7 indicates completely agree:

1. I think about how things can change in the future and try to influence those things in my everyday life.

2. I often work on things that will only pay off in a couple of years.

3. I am only concerned about the present, because I trust that things will work themselves out in the future. (reverse coded)

4. With everything I do, I am only concerned about the immediate consequences (say, a period of a couple of days or weeks). (reverse coded)

5. Whether something is convenient for me or not to a large extent determines the decisions that I take or the actions that I undertake. (reverse coded)

6. I am ready to sacrifice my well-being in the present to achieve certain results in the future.

7. I think it is important to take warnings about the negative consequences of my actions seriously, even if these negative consequences would only occur in the distant future.

8. I think it is more important to work on things that have important consequences in the future than to work on things that have immediate but less important consequences.

9. In general, I ignore warnings about future problems because I think these problems will be solved before they get critical. (reverse coded) 
10. I think there is no need to sacrifice things now for problems that lie in the future, because it will always be possible to solve these future problems later. (reverse coded)

11. I only respond to urgent problems, trusting that problems that come up later can be solved in a later stage. (reverse coded)

12. I get clear results in my daily work and this is more important to me than getting vague results. (reverse coded)

\section{Appendix B. Additional Tables and Figures}

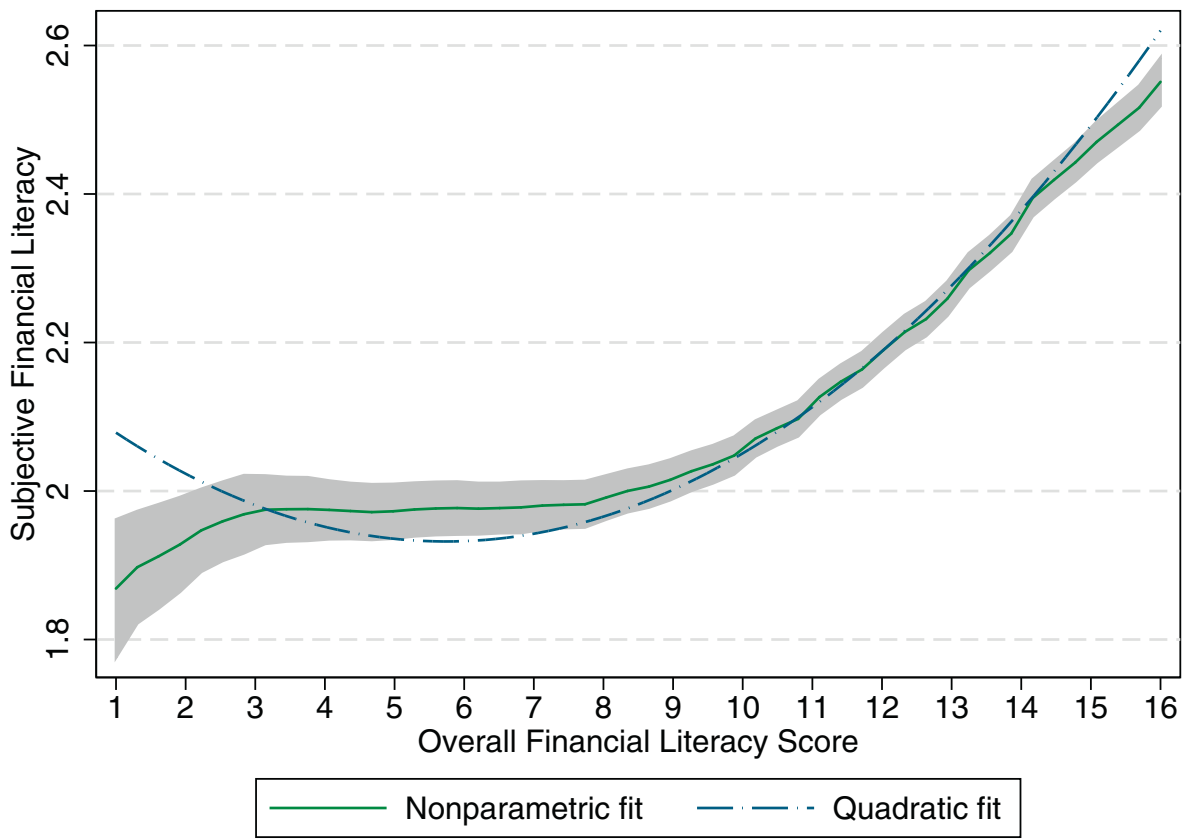

Fig. B1. relation between subjective and objective financial literacy, for constructing overconfidence.

Table B1

Summary statistics of key variables in the DHS.

\begin{tabular}{lllll}
\hline & Obs. & Mean & Min & Max \\
\hline Internal economic locus of control (unstandardized) & 18,420 & 4.55 & 1.92 & 6.96 \\
Owns equity & 18,420 & 0.29 & 0.00 & 1.00 \\
Owns stocks & 18,420 & 0.14 & 0.00 & 1.00 \\
Owns mutual funds & 18,420 & 0.22 & 0.00 & 1.00 \\
Owns bonds & 18,420 & 0.04 & 0.00 & 1.00 \\
Owns other assets & 18,420 & 0.02 & 0.00 & 1.00 \\
Household financial wealth (thousands of $€$ ) & 18,420 & 39.0 & 0.00 & 3,703 \\
Share of wealth in equity & 18,420 & 0.12 & 0.00 & 1.00 \\
Share of wealth in stocks & 18,420 & 0.04 & 0.00 & 1.00 \\
Share of wealth in mutual funds & 18,420 & 0.08 & 0.00 & 1.00 \\
Share of wealth in bonds & 18,420 & 0.01 & 0.00 & 1.00 \\
Share of wealth in other assets & 18,420 & 0.01 & 0.00 & 0.99 \\
Age & 18,420 & 52.7 & 25.0 & 80.0 \\
Female & 18,420 & 0.42 & 0.00 & 1.00 \\
High school educated & 18,247 & 0.37 & 0.00 & 1.00 \\
University educated & 18,247 & 0.42 & 0.00 & 1.00 \\
Household type: & & & & \\
Living alone & 18,420 & 0.26 & 0.00 & 1.00 \\
Living with partner, no kids & 18,420 & 0.40 & 0.00 & 1.00 \\
Living with partner and kids & 18,420 & 0.30 & 0.00 & 1.00 \\
Living with kids & 18,420 & 0.03 & 0.00 & 1.00 \\
Other & 18,420 & 0.01 & 0.00 & 1.00 \\
People in household & 18,420 & 2.38 & 1.00 & 8.00 \\
OCcupation: & & & &
\end{tabular}


Table B1 (continued)

\begin{tabular}{|c|c|c|c|c|}
\hline & Obs. & Mean & Min & Max \\
\hline Employed & 18,420 & 0.54 & 0.00 & 1.00 \\
\hline Own business & 18,420 & 0.01 & 0.00 & 1.00 \\
\hline Self-employed & 18,420 & 0.04 & 0.00 & 1.00 \\
\hline Unemployed & 18,420 & 0.02 & 0.00 & 1.00 \\
\hline Works own household & 18,420 & 0.11 & 0.00 & 1.00 \\
\hline Retired & 18,420 & 0.26 & 0.00 & 1.00 \\
\hline Volunteer & 18,420 & 0.02 & 0.00 & 1.00 \\
\hline Other & 18,420 & 0.01 & 0.00 & 1.00 \\
\hline \multicolumn{5}{|l|}{ Region: } \\
\hline Three largest cities & 18,339 & 0.16 & 0.00 & 1.00 \\
\hline Other West & 18,339 & 0.28 & 0.00 & 1.00 \\
\hline North & 18,339 & 0.11 & 0.00 & 1.00 \\
\hline East & 18,339 & 0.21 & 0.00 & 1.00 \\
\hline South & 18,339 & 0.24 & 0.00 & 1.00 \\
\hline Risk aversion (unstandardized) & 18,277 & 5.25 & 1.50 & 7.00 \\
\hline Patience (unstandardized) & 18,381 & 4.17 & 1.00 & 6.58 \\
\hline \multicolumn{5}{|l|}{ Household yearly net income: } \\
\hline Less than $€ 10,000$ & 16,520 & 0.03 & 0.00 & 1.00 \\
\hline Between $€ 10,000$ and $€ 14,000$ & 16,520 & 0.04 & 0.00 & 1.00 \\
\hline Between $€ 14,000$ and $€ 22,000$ & 16,520 & 0.10 & 0.00 & 1.00 \\
\hline Between $€ 22,000$ and $€ 40,000$ & 16,520 & 0.30 & 0.00 & 1.00 \\
\hline Between $€ 40,000$ and $€ 75,000$ & 16,520 & 0.39 & 0.00 & 1.00 \\
\hline$€ 75,000$ or more & 16,520 & 0.12 & 0.00 & 1.00 \\
\hline Don't know & 16,520 & 0.02 & 0.00 & 1.00 \\
\hline Household financial wealth (thousands of $€$ ) & 18,420 & 62.8 & $-1,791$ & 5,234 \\
\hline Expected returns & 816 & 0.02 & -0.48 & 0.40 \\
\hline Expected S.D of returns & 816 & 0.12 & 0.01 & 0.68 \\
\hline High subjective financial literacy & 18,420 & 0.47 & 0.00 & 1.00 \\
\hline High objective financial literacy & 12,279 & 0.49 & 0.00 & 1.00 \\
\hline Total financial literacy score & 12,279 & 10.7 & 0.00 & 16.0 \\
\hline Overconfidence & 12,279 & 0.00 & -1.60 & 2.07 \\
\hline Experience: Years investing in equity & 18,420 & 1.98 & 0.00 & 22.0 \\
\hline Optimism & 10,351 & 10.8 & 3.00 & 15.0 \\
\hline Trust & 10,145 & 0.42 & 0.00 & 1.00 \\
\hline
\end{tabular}

Table B2

Ownership of different types of financial assets, subjective return and risk expectations, and internal economic locus of control.

\begin{tabular}{|c|c|c|c|c|}
\hline Dependent variable: Ownership of & $\begin{array}{l}\text { Stocks } \\
\text { (1) }\end{array}$ & $\begin{array}{l}\text { Mutual funds } \\
\text { (2) }\end{array}$ & $\begin{array}{l}\text { Bonds } \\
\text { (3) }\end{array}$ & $\begin{array}{l}\text { Other assets } \\
\text { (4) }\end{array}$ \\
\hline \multicolumn{5}{|c|}{ Panel A } \\
\hline Subjective expected return mean & $\begin{array}{l}0.003^{*} \\
(0.002)\end{array}$ & $\begin{array}{l}0.004 * * \\
(0.002)\end{array}$ & $\begin{array}{l}0.000 \\
(0.001)\end{array}$ & $\begin{array}{l}-0.001 \\
(0.001)\end{array}$ \\
\hline Subjective expected return S.D. & $\begin{array}{l}-0.001 \\
(0.001)\end{array}$ & $\begin{array}{l}0.001 \\
(0.002)\end{array}$ & $\begin{array}{l}-0.000 \\
(0.001)\end{array}$ & $\begin{array}{l}-0.001 \\
(0.001)\end{array}$ \\
\hline$R^{2}$ & 0.23 & 0.21 & 0.10 & 0.04 \\
\hline \multicolumn{5}{|c|}{ Panel B } \\
\hline Internal economic locus of control & $\begin{array}{l}0.017^{*} \\
(0.009)\end{array}$ & $\begin{array}{l}0.015 \\
(0.011)\end{array}$ & $\begin{array}{l}0.006 \\
(0.006)\end{array}$ & $\begin{array}{l}0.000 \\
(0.004)\end{array}$ \\
\hline$R^{2}$ & 0.22 & 0.21 & 0.10 & 0.04 \\
\hline \multicolumn{5}{|c|}{ Panel C } \\
\hline Internal economic locus of control & $\begin{array}{l}0.018^{*} \\
(0.009)\end{array}$ & $\begin{array}{l}0.014 \\
(0.011)\end{array}$ & $\begin{array}{l}0.006 \\
(0.006)\end{array}$ & $\begin{array}{l}0.000 \\
(0.004)\end{array}$ \\
\hline Subjective expected return mean & $\begin{array}{l}0.002 \\
(0.002)\end{array}$ & $\begin{array}{l}0.004^{*} \\
(0.002)\end{array}$ & $\begin{array}{l}0.000 \\
(0.001)\end{array}$ & $\begin{array}{l}-0.001 \\
(0.001)\end{array}$ \\
\hline
\end{tabular}


Table B2 (continued)

\begin{tabular}{lllll}
\hline Dependent variable: Ownership of & $\begin{array}{l}\text { Stocks } \\
(1)\end{array}$ & $\begin{array}{l}\text { Mutual funds } \\
(2)\end{array}$ & $\begin{array}{l}\text { Bonds } \\
(3)\end{array}$ & $\begin{array}{l}\text { Other assets } \\
(4)\end{array}$ \\
\hline Subjective expected return S.D. & $\begin{array}{l}-0.000 \\
(0.001)\end{array}$ & $\begin{array}{l}0.001 \\
(0.002)\end{array}$ & $\begin{array}{l}-0.000 \\
(0.001)\end{array}$ & $\begin{array}{l}-0.001 \\
(0.001)\end{array}$ \\
$R^{2}$ & 0.23 & 0.21 & 0.10 & 0.04 \\
\hline Socio-demographic characteristics: & Yes & Yes & Yes & Yes \\
Income and wealth: & Yes & Yes & Yes & Yes \\
Observations & 2,249 & 2,249 & 2,249 & 2,249 \\
Households & 1,421 & 1,421 & 1,421 & 1,421 \\
\hline
\end{tabular}

Linear probability model (OLS) coefficients. The dependent variable is a dummy that takes the value of one if the respondent household owns any of the assets marked above. Other assets include mostly financial real estate. Socio-demographic characteristics include a quadratic polynomial for age and dummies for gender, education, marital status, household composition, household size, and household head occupation. Income and wealth include six dummies for net household income and three dummies for household wealth quartiles. All regressions include year-by-region fixed effects and additional dummies for imputed controls. Standard errors clustered at the household level in parenthesis. ${ }^{* * *}$ denotes significance at the $1 \%$ level, ** at the $5 \%$ level, and * at the $10 \%$ level.

Table B3

Internal economic locus of control and investor experience.

\begin{tabular}{lllll}
\hline $\begin{array}{l}\text { Dependent variable: Time-varying measure } \\
\text { of internal economic locus of control }\end{array}$ & $(1)$ & $(2)$ & $(3)$ & $(4)$ \\
\hline Experience: Years investing in equity & $\begin{array}{l}0.029^{* * *} \\
\text { (0.006) }\end{array}$ & $\begin{array}{l}0.015^{* *} \\
(0.006)\end{array}$ & $\begin{array}{l}-0.000 \\
(0.004)\end{array}$ & $\begin{array}{l}0.002 \\
(0.008)\end{array}$ \\
First measure of internal locus of control & & & $0.780^{* * *}$ & \\
& & & $(0.018)$ & \\
Socio-demographic characteristics: & No & Yes & Yes & Yes \\
Risk aversion and patience: & No & Yes & Yes & Yes \\
Income and wealth: & No & Yes & Yes & Yes \\
Household fixed effects: & No & No & No & Yes \\
$R^{2}$ & 0.02 & 0.14 & 0.56 & - \\
Observations & 7682 & 7682 & 7682 & 7682 \\
Households & 2765 & 2765 & 2765 & 2765 \\
\hline
\end{tabular}

OLS regression coefficients. The dependent variable is a time-varying measure of internal locus of control, constructed as the within-year mean of the 13 items used in the DHS. Experience is the cumulative number of years a household has held equity in the past, as observed in the DHS. The first measure of locus of control is time-constant. Socio-demographic characteristics include a quadratic polynomial for age and dummies for gender, education, marital status, household composition, household size, and household head occupation. Income and wealth include six dummies for net household income and three dummies for household wealth quartiles. All regressions include year-by-region fixed effects and additional dummies for imputed controls. Standard errors clustered at the household level in parenthesis. ${ }^{* * *}$ denotes significance at the $1 \%$ level, ${ }^{* *}$ at the $5 \%$ level, and * at the $10 \%$ level.

Table B4

Equity ownership and internal economic locus of control using Obviously Related Instrumental Variable (ORIV) estimators.

\begin{tabular}{lllll}
\hline Dependent variable: Equity ownership & $(1)$ & $(2)$ & $(3)$ & $(4)$ \\
\hline Internal economic locus of control & $0.035^{* * *}$ & $0.038^{* *}$ & $0.029^{* * *}$ & $0.036^{* * *}$ \\
& $(0.005)$ & $(0.016)$ & $(0.005)$ & $(0.006)$ \\
& {$[125.893]$} & {$[42.594]$} & {$[124.792]$} & {$[121.552]$} \\
Risk aversion & $-0.165^{* * *}$ & $-0.166^{* * *}$ & $-0.159^{* * *}$ & $-0.167^{* * *}$ \\
& $(0.005)$ & $(0.017)$ & $(0.006)$ & $(0.006)$ \\
Patience & {$[107.815]$} & {$[36.933]$} & {$[106.892]$} & {$[101.964]$} \\
& $0.027^{* * *}$ & $0.037^{* *}$ & $0.023^{* * *}$ & $0.025^{* * *}$ \\
& $(0.005)$ & $(0.015)$ & $(0.005)$ & $(0.006)$ \\
& {$[119.709]$} & {$[42.384]$} & {$[119.129]$} & {$[113.873]$}
\end{tabular}

(continued on next page) 
Table B4 (continued)

\begin{tabular}{|c|c|c|c|c|}
\hline Dependent variable: Equity ownership & $(1)$ & $(2)$ & (3) & $(4)$ \\
\hline Subjective expected return mean & & $\begin{array}{l}0.014 * \\
(0.008) \\
{[13.440]}\end{array}$ & & \\
\hline Subjective expected return S.D. & & $\begin{array}{l}-0.006 \\
(0.005) \\
{[16.172]}\end{array}$ & & \\
\hline Subjective financial literacy (1-4 scale) & & & $\begin{array}{l}0.063^{* * *} \\
(0.009) \\
{[133.225]}\end{array}$ & \\
\hline Openness & & & & $\begin{array}{l}0.012 * * \\
(0.005) \\
{[166.152]}\end{array}$ \\
\hline Conscientiousness & & & & $\begin{array}{l}-0.033^{* * *} \\
(0.005) \\
{[143.415]}\end{array}$ \\
\hline Extraversion & & & & $\begin{array}{l}-0.024^{* * *} \\
(0.005) \\
{[179.209]}\end{array}$ \\
\hline Agreeableness & & & & $\begin{array}{l}0.023 * * * \\
(0.007) \\
{[124.678]}\end{array}$ \\
\hline Neuroticism & & & & $\begin{array}{l}-0.003 \\
(0.005) \\
{[142.276]}\end{array}$ \\
\hline Socio-demographic characteristics: & Yes & Yes & Yes & Yes \\
\hline Income and wealth: & Yes & Yes & Yes & Yes \\
\hline $3 S L S R^{2}$ & 0.29 & 0.27 & 0.30 & 0.31 \\
\hline Observations & 15,832 & 2,005 & 15,832 & 13,600 \\
\hline Households & 1,962 & 1,224 & 1,962 & 1,541 \\
\hline
\end{tabular}

Obviously Related Instrumental variable (ORIV) estimates. The dependent variable is a dummy that takes the value of one if the respondent household owns any equity. First-time measures of internal economic locus of control, risk aversion, patience, subjective financial literacy in a 1-to-4 scale, and the Big Five each used as instrument for its corresponding time-constant measure in subsequent years. Subjective market return and risk expectations in 2004 used as instruments for 2006 expectations, and 2006 used as instruments for 2004 expectations. T-statistics of each first-stage in square brackets under each corresponding coefficient. Sociodemographic characteristics include a quadratic polynomial for age and dummies for gender, education, marital status, household composition, household size, and household head occupation. Income and wealth include six dummies for net household income and three dummies for household wealth quartiles. All regressions include year-by-region fixed effects and additional dummies for imputed controls. Standard errors clustered at the household level in parenthesis. *** denotes significance at the $1 \%$ level, ${ }^{* *}$ at the $5 \%$ level, and $*$ at the $10 \%$ level.

\section{Appendix C. The Relation Between Internal Locus of Control and Subjective Risk Perception as Revealed by Investment in Financial Options}

An indirect test of the relation between locus of control and subjective risk perception can be performed by exploiting the relation between the prices of financial options (one of the components of a household's investments in risky assets) and the return variance of their underlying assets. This appendix explains and conducts this test.

A lower subjective variance of returns encourages risk-averse households to hold relatively more of almost all types of equity. Financial options, however, work as insurance contracts against asset value losses, and because of this they become more valuable when the underlying asset value becomes more volatile. Options on more volatile underlying assets insure against more uncertain outcomes, making the implicit insurance they provide more valuable (see Black and Scholes, 1973). The relation between option prices and risk is strictly true for the implied volatility of the underlying asset. However, to the extent that implied volatility is predictive of future volatility-as shown by, for example, Fleming (1998)-the positive relation between perceived risk and option prices should hold. This gives us a testable implication we can use for further testing whether internal locus of control is related to lower subjective variance of returns.

Now consider the subjective pricing of options for investors with different degrees of internal locus of control linked to their subjective perceptions. We have shown that investors with an internal locus of control are more likely to own equity altogether. However, within equity holders, if those with a stronger internal economic locus of control also have lower subjective perception of risk, they will consider the market price of financial options as relatively high compared to their own valuation. Therefore, for a given option price, internal locus of control investors will be more likely to sell options and 


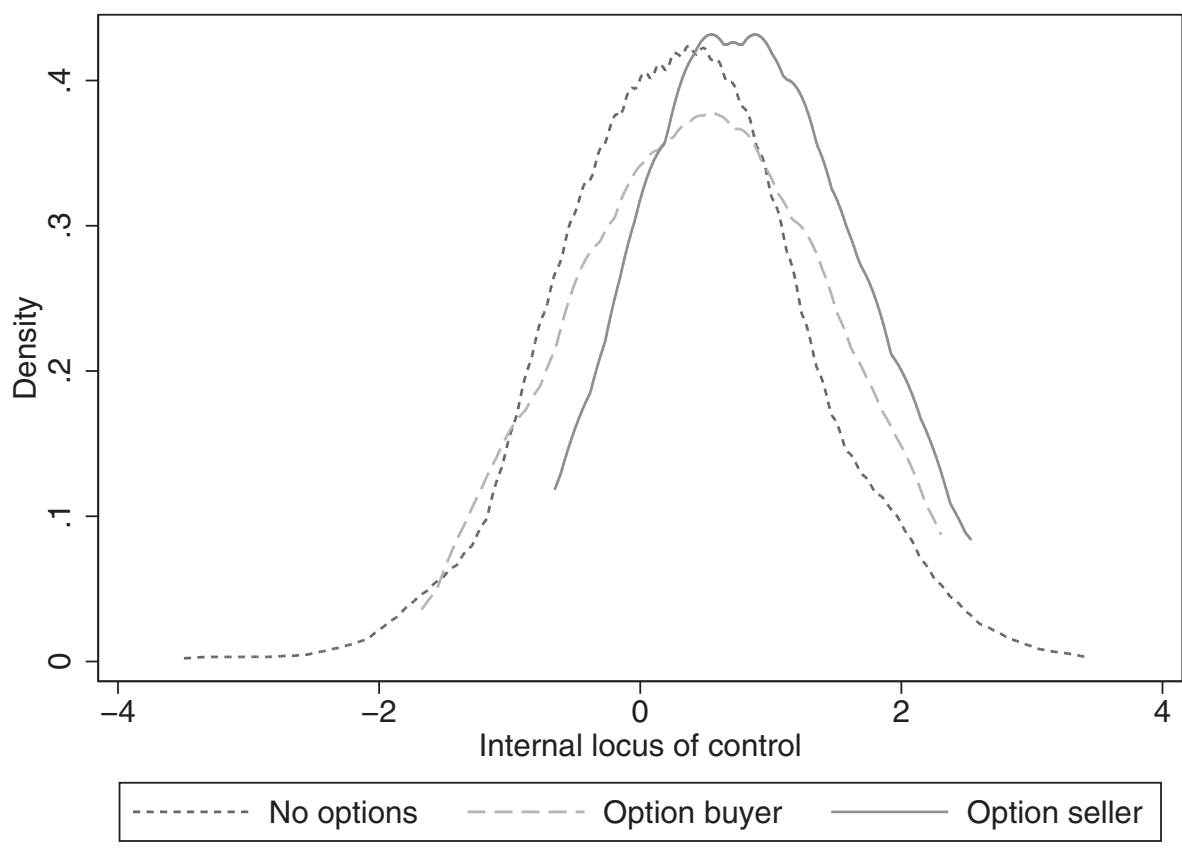

Fig. C1. Distributions of internal economic locus of control for option non-investors, option buyers, and option sellers.

Table C1

Ownership of financial options and internal economic locus of control.

\begin{tabular}{llll}
\hline Investor Outcome: & $\begin{array}{l}\text { Option buyer } \\
(1)\end{array}$ & $\begin{array}{l}\text { Option seller } \\
(2)\end{array}$ & $\begin{array}{l}\text { Buyer \& seller } \\
(3)\end{array}$ \\
\hline Internal economic locus of control & 1.272 & $1.501^{* *}$ & 0.953 \\
& $(0.254)$ & $(0.306)$ & $(0.197)$ \\
Risk aversion & $0.580^{* *}$ & $0.324^{* * *}$ & $0.541^{* * *}$ \\
& $(0.128)$ & $(0.079)$ & $(0.124)$ \\
Patience & 1.008 & 1.181 & 0.806 \\
& $(0.243)$ & $(0.248)$ & $(0.237)$ \\
Base outcome: & Has equity but not options & \\
Socio-demographic characteristics: & Yes & & \\
Risk aversion and patience: & Yes & & \\
Income and wealth: & Yes & & \\
Observations & 5,283 & \\
Households & 1,163 & & \\
\hline
\end{tabular}

Multinomial logit odds ratios. The dependent variable categorizes households based on whether they sold financial options, they bought them, they did both, or they did neither in a given DHS wave. Model conditional on owning equity. Socio-demographic characteristics include a quadratic polynomial for age and dummies for gender, education, marital status, household composition, household size, and household head occupation. Income and wealth include six dummies for net household income and three dummies for household wealth quartiles. All regressions include year-by-region fixed effects and additional dummies for imputed controls. Standard errors clustered at the household level in parenthesis. ${ }^{* * *}$ denotes significance at the $1 \%$ level, ${ }^{* *}$ at the $5 \%$ level, and ${ }^{*}$ at the $10 \%$ level.

less likely to buy them. This prediction runs contrary to the effect predicted by locus of control having the same effect on options as on all other equity sub-classes. We expect that if locus of control is linked to subjective risk perceptions, internal locus of control will have a positive effect on option selling and a negative one on option buying.

The DHS collects information on the respondents' types of option investments. In particular, it asks whether households have open positions in financial options and whether they bought or sold them. Using the sub-sample of equity investors only, we estimate a multinomial model for being an option seller, an option buyer, or both a seller and a buyer (the reference category is holding equity but no options). The estimation results (Fig. C.1 and Table C.1 below) show a positive effect of internal economic locus of control on the likelihood of selling options. For buyers, the relation is negative, though not significant, in spite of the fact that buyers are more prevalent than sellers in our data. Our test thus provides indirect evidence supporting the hypothesis that internal locus of control is related to lower subjective risk perceptions. 


\section{Supplementary material}

\section{Supplementary material associated with this article can be found, in the online version, at doi:10.1016/j.jebo.2020.06.032}

\section{References}

Agnew, J., Szykman, L., 2005. Asset allocation and information overload: the influence of information display, asset choice, and investor experience. J. Behav. Financ. 6 (2), 57-70.

Albanese, G., De Blasio, G., Sestito, P., 2013. Trust and Preferences: Evidence From Survey Data. Bank of Italy Temi di Discussione (Working Paper) 911.

Almlund, M., Duckworth, A.L., Heckman, J., Kautz, T., 2011. Personality psychology and economics. In: Handbook of the Economics of Education, 4. Elsevier, pp. $1-181$.

Baranov, V., Kohler, H.-P., 2018. The impact of aids treatment on savings and human capital investment in malawi. Am. Econ. J. 10 (1), $266-306$.

Barber, B.M., Odean, T., 2001. Boys will be boys: gender, overconfidence, and common stock investment. Q. J. Econ. 116 (1), $261-292$.

Barrick, M., Mount, M., Gupta, R., 2003. Meta-analysis of the relationship between the five-factor model of personality and Holland's occupational types. Person. Psychol. 56 (1), 45-74.

Benzoni, L., Collin-Dufrense, P., Goldstein, R., 2007. Portfolio choice over the life-cycle when the stock and labor markets are cointegrated. J. Financ. 62 (5), 2123-2167.

Black, F., Scholes, M., 1973. The pricing of options and corporate liabilities. J. Polit. Econ. 81 (3), 637-654

Bodie, Z., Merton, R., Samuelson, W., 1992. Labor supply flexibility and portfolio choice in a life cycle model. J. Econ. Dyn. Control 16 (3-4), 427-449.

Borghans, L., Duckworth, A., Heckman, J., ter Weel, B., 2008. The economics and psychology of personality traits. J. Hum. Resour. 43 (4), $972-1059$.

Borghans, L., Golsteyn, B., 2006. Time discounting and the body mass index: evidence from the netherlands. Econ. Hum. Biol. 4 (1), 39-61.

Bowles, S., Gintis, H., Osborne, M., 2001a. Incentive-enhancing preferences: personality, behavior, and earnings. Am. Econ. Rev. 91 (2), 155-158.

Bowles, S., Gintis, H., Osborne, M., 2001b. The determinants of earnings: a behavioral approach. J. Econ. Lit. 39 (4), 1137-1176.

Caliendo, M., Cobb-Clark, D.A., Obst, C., Seitz, H., Uhlendorff, A., 2020. Locus of control and investment in training. J. Hum. Resour. 0318-9377R2.

Caliendo, M., Cobb-Clark, D.A., Uhlendorff, A., 2015. Locus of control and job search strategies. Rev. Econ. Stat. 97 (1), 88-103.

Cebi, M., 2007. Locus of control and human capital investment revisited. J. Hum. Resour. 42 (4), 919-932.

Chatterjee, S., Finke, M., Harness, N., 2009. Individual wealth management: does self-esteem matter? J. Appl. Bus. Econ. 10 (2), 1-14.

Christelis, D., Jappelli, T., Padula, M., 2010. Cognitive abilities and portfolio choice. Eur. Econ. Rev. 54 (1), $18-38$.

Cobb-Clark, D.A., Kassenboehmer, S.C., Schurer, S., 2014. Healthy habits: the connection between diet, exercise, and locus of control. J. Econ. Behav. Organ. $98,1-28$

Cobb-Clark, D.A., Kassenboehmer, S.C., Sinning, M.G., 2016. Locus of control and savings. J. Bank. Financ. 73, 113-130.

Cobb-Clark, D.A., Schurer, S., 2012. The stability of big-five personality traits. Econ. Lett. 115 (1), 11-15. doi:10.1016/j.econlet.2011.11.015.

Cobb-Clark, D.A., Schurer, S., 2013. Two economists' musings on the stability of locus of control. Econ. J. 123 (570), F358-F400.

Cocco, J., Gomes, F., Maenhout, P., 2005. Consumption and portfolio choice over the life cycle. Rev. Financ. Stud. 18 (2), $491-533$.

Coleman, M., DeLeire, T., 2003. An economic model of locus of control and the human capital investment decision. J. Hum. Resour. 38 (3), 701-721.

De Bondt, W.F.M., 1998. A portrait of the individual investor. Eur. Econ. Rev. 42 (3-5), 831-844.

Delavande, A., Kohler, H.-P., 2016. Hiv/aids-related expectations and risky sexual behaviour in malawi. Rev. Econ. Stud. 83 (1), $118-164$

Dohmen, T., Falk, A., Huffman, D., Sunde, U., Schupp, J., Wagner, G.G., 2011. Individual risk attitudes: measurement, determinants, and behavioral consequences. J. Eur. Econ. Assoc. 9 (3), 522-550.

Donnellan, M., Lucas, R., 2008. Age differences in the big five across the life span: evidence from two national samples. Psychol. Aging 23 (3), 558-566.

Durand, R., Newby, R., Sanghani, J., 2008. An intimate portrait of the individual investor. J. Behav. Financ. 9 (4), 193-208.

Elkins, R., Schurer, S., et al., 2020. Exploring the role of parental engagement in non-cognitive skill development over the lifecourse. J. Popul. Econ. 33 (3), 957-1004.

Elkins, R.K., Kassenboehmer, S.C., Schurer, S., 2017. The stability of personality traits in adolescence and young adulthood. J. Econ. Psychol. 60, 37-52.

Evans, D., Leighton, L., 1989. Some empirical aspects of entrepreneurship. Am. Econ. Rev. 79 (3), 519-535.

Fleming, J., 1998. The quality of market volatility forecasts implied by s\&p 100 index option prices. J. Empir. Financ. 5 (4), $317-345$.

Frijling, B.D., Lobo, C.M., Keus, I.M., Jenks, K.M., Akkermans, R.P., Hulscher, M.E., Prins, A., van der Wouden, J.C., Grol, R.P., 2004. Perceptions of cardiovascular risk among patients with hypertension or diabetes. Patient Educ. Couns. 52 (1), 47-53.

Furnham, A., 1986. Economic locus of control. Hum. Relat. 39 (1), 29-43.

Gervais, S., Odean, T., 2001. Learning to be overconfident. Rev. Financ. Stud. 14 (1), 1-27.

Gillen, B., Snowberg, E., Yariv, L., 2019. Experimenting with measurement error: techniques with applications to the caltech cohort study. J. Polit. Econ. 127 (4), 1826-1863.

Goldberg, L., 1993. The structure of phenotypic personality traits. Am. Psychol. 48, 26-27.

Goldberg, L.R., 1992. The development of markers for the big-five factor structure.. Psychol. Assess. 4 (1), 26.

Goldberg, L. R., 1999. International personality item pool: a scientific collaboratory for the development of advanced measures of personality and other individual differences. Retrieved August 14, 2002

Gomes, F., Michaelides, A., 2005. Optimal life-cycle asset allocation: understanding the empirical evidence. J. Financ. 60 (2), $869-904$.

Grinblatt, M., Keloharju, M., 2009. Sensation seeking, overconfidence, and trading activity. J. Financ. 64 (2), $549-578$.

Guarnera, S., Williams, R., 1987. Optimism and locus of control for health and affiliation among elderly adults. J. Gerontol. 42 (6), $594-595$.

Guiso, L., Sapienza, P., Zingales, L., 2008. Trusting the stock market. J. Financ. 63 (6), 2557-2600.

Heckman, J.J., Stixrud, J., Urzua, S., 2006. The effects of cognitive and noncognitive abilities on labor market outcomes and social behavior. J. Labor Econ. 24 (3), 411-482.

Heineck, G., Anger, S., 2010. The returns to cognitive abilities and personality traits in germany. Lab. Econ. 17 (3), 535-546.

Hong, H., Kubik, J.D., Stein, J.C., 2004. Social interaction and stock-market participation. J. Financ. 59 (1), $137-163$.

Hoorens, V., Buunk, B., 1993. Social comparison of health risks: locus of control, the person-positivity bias, and unrealistic optimism. J. Appl. Soc. Psychol. 23 (4), 291-302.

Hurd, M., Van Rooij, M., Winter, J., 2011. Stock market expectations of dutch households. J. Appl. Econ. 26 (3), $416-436$.

Jensen, R., 2010. The (perceived) returns to education and the demand for schooling. Q. J. Econ. 125 (2), $515-548$.

Jia, J.S., Khan, U., Litt, A., 2015. The effect of self-control on the construction of risk perceptions. Manag. Sci. 61 (9), $2259-2280$.

Judge, T.A., Erez, A., Bono, J.E., Thoresen, C.J., 2002. Are measures of self-esteem, neuroticism, locus of control, and generalized self-efficacy indicators of a common core construct? J. Personal. Soc. Psychol. 83 (3), 693.

Kallmen, H., 2000. Manifest anxiety, general self-efficacy and locus of control as determinants of personal and general risk perception. J. Risk Res. 3 (2), 111-120.

Kapteyn, A., Teppa, F., 2011. Subjective measures of risk aversion, fixed costs, and portfolio choice. J. Econ. Psychol. 32 (4), $564-580$.

Malmendier, U., Tate, G., 2005. Ceo overconfidence and corporate investment. J. Financ. 60 (6), 2661-2700.

McGee, A., McGee, P., 2016. Search, effort, and locus of control. J. Econ. Behav. Organ. 126, 89-101.

McGee, A.D., 2015. How the perception of control influences unemployed job search. ILR Rev. 68 (1), $184-211$.

McInish, T., 1982. Individual investors and risk-taking. J. Econ. Psychol. 2 (2), 125-136. 
Merton, R., 1969. Lifetime portfolio selection under uncertainty: the continuous-time case. Rev. Econ. Stat. 51 (3), $247-257$.

Oehler, A., Wendt, S., Wedlich, F., Horn, M., 2018. Investors' personality influences investment decisions: experimental evidence on extraversion and neuroticism. J. Behav. Financ. 19 (1), 30-48.

Pinger, P., Schäfer, S., Schumacher, H., 2018. Locus of control and consistent investment choices. J. Behav. Exp. Econ. 75, 66-75.

Plunkett, H., Buehner, M., 2007. The relation of general and specific locus of control to intertemporal monetary choice. Person. Individ. Differ. 42 (7), $1233-1242$.

Puri, M., Robinson, D., 2007. Optimism and economic choice. J. Financ. Econ. 86 (1), 71-99.

Roberts, B., DelVecchio, W., 2000. The rank-order consistency of personality traits from childhood to old age: a quantitative review of longitudinal studies.. Psychol. Bull. 126 (1), 3-25.

Rotter, J., 1966. Generalized expectancies for internal versus external control of reinforcement. Psychol. Monogr. 80 (1), 1-28.

Rotter, J.B., 1990. Internal versus external control of reinforcement: acase history of a variable.. Am. Psychol. 45 (4), $489-493$.

Salamanca, N., 2018. The Dynamic Properties of Economic Preferences. Melbourne Institute Working Paper No. 04/18.

Samuelson, P., 1969. Lifetime portfolio selection by dynamic stochastic programming. Rev. Econ. Stat. 51 (3), $239-246$.

Scheier, M.F., Carver, C.S., Bridges, M.W., 1994. Distinguishing optimism from neuroticism (and trait anxiety, self-mastery, and self-esteem): a reevaluation of the life orientation test.. J. Personal. Soc. Psychol. 67 (6), 1063-1078.

Schurer, S., 2017. Bouncing back from health shocks: locus of control and labor supply. J. Econ. Behav. Organ. 133, 1-20.

Sherman, L., 1984. Development of children's perceptions of internal locus of control: a cross-sectional and longitudinal analysis. J. Personal. 52 (4), $338-354$.

Simon, M., Houghton, S.M., Aquino, K., 2000. Cognitive biases, risk perception, and venture formation: how individuals decide to start companies. J. Bus. Vent. 15 (2), 113-134.

Sjöberg, L., 2000. Factors in risk perception. Risk Anal. 20 (1), 1-11.

Slovic, P., 1992. Perception of risk: Reflections on the psychometric paradigm. Soc. Theor. Risk 117-152.

Stock, J.H., Watson, M.W., 2015. Introduction to econometrics, third ed. Pearson Education Limited. update, global edition

Strathman, A., Gleicher, F., Boninger, D., Edwards, C., 1994. The consideration of future consequences: weighing immediate and distant outcomes of behavior. J. Personal. Soc. Psychol. 66 (4), 742-752.

Svensson, L., 1989. Portfolio choice with non-expected utility in continuous time. Econ. Lett. 30 (4), $313-317$.

Teppa, F., Vis, C., et al., 2012. The CentERpanel and the DNB Household Survey: Methodological Aspects. Technical Report. Netherlands Central Bank, Research Department.

Tokunaga, H., 1993. The use and abuse of consumer credit: application of psychological theory and research. J. Econ. Psychol. 14 (2), $285-316$.

Van Daalen, H., Van Niekerk, E., Pottas, C., 2008. The validation of Furnham's locus of control scale for a black southern African group. SA J. Ind. Psychol. $15(1), 12-21$.

Van Rooij, M., Lusardi, A., Alessie, R., 2011. Financial literacy and stock market participation. J. Financ. Econ. 60 (2-3), 401-448.

Warneryd, K., 1996. Risk attitudes and risky behavior. J. Econ. Psychol. 17 (6), 749-770.

Weber, M., Weber, E.U., Nosić, A., 2013. Who takes risks when and why: determinants of changes in investor risk taking. Rev. Financ. 17 (3), $847-883$.

Wiswall, M., Zafar, B., 2015. Determinants of college major choice: identification using an information experiment. Rev. Econ. Stud. 82 (2), 791-824.

Wooldridge, J.M., 2007. Inverse probability weighted estimation for general missing data problems. J. Econ. 141 (2), $1281-1301$. 